NASA Technical Memorandum 106976

AIAA-95-2995

\title{
Jet Mixing and Emission Characteristics of Transverse Jets in Annular and Cylindrical Confined Crossflow
}

D.B. Bain and C.E. Smith

CFD Research Corporation

Huntsville, Alabama

J.D. Holdeman

Lewis Research Center

Cleveland, Ohio

Prepared for the

31st Joint Propulsion Conference and Exhibit cosponsored by AIAA, ASME, SAE, and ASEE San Diego, California, July 10-12, 1995

National Aeronautics and

Space Administration 
Jet Mixing and Emission Characteristics of Transverse Jets

in Annular and Cylindrical Confined Crossflow

\author{
D. B. Bain* and C. E. Smith ${ }^{* *}$ \\ CFD Research Corporation \\ Huntsville, Alabama \\ J. D. Holdeman ${ }^{* * *}$ \\ NASA Lewis Research Center \\ Cleveland, Ohio
}

\begin{abstract}
$\underline{\text { Abstract }}$
3-D turbulent reacting CFD analyses were performed on

transverse jets injected into annular and cylindrical (can)

confined crossflows. The goal of this study was to identify and assess mixing differences between annular and can geometries. The approach was to optimize both annular and can configurations by systematically varying orifice spacing until lowest emissions were achieved, and then compare the results. Numerical test conditions consisted of a jet-to-mainstream mass-flow ratio of 3.2 and a jet-to-mainstream momentum-flux ratio $(\mathrm{J})$ of 30 .

The computational results showed that the optimized geometries had similar emission levels at the exit of the mixing section although the annular configuration did mix-out faster. For lowest emissions, the design correlation parameter $(\mathrm{C}=(\mathrm{S} / \mathrm{H}) \sqrt{\mathrm{J}})$ was 2.35 for the annular geometry and 3.5 for the can geometry. For the annular geometry, the constant was about twice the value seen for jet mixing at low mass-flow ratios (i.e. MR < 0.5). For the can geometry, the constant was about $11 / 2$ times the value seen for low mass-flow ratios.
\end{abstract}

Nomenclature

f Mixture Fraction

$\begin{array}{ll}\mathrm{h} & \text { Enthalpy } \\ \mathrm{k}_{\infty} & \text { Turbulent Kinetic Energy of Mainstrea } \\ \mathrm{m}_{\mathrm{j}} & \text { Mass Flow of Jets } \\ \mathrm{m}_{\infty} & \text { Mass Flow of Mainstream } \\ \mathrm{x} & \begin{array}{l}\text { Axial Coordinate, } \mathrm{x}=0 \text { at leading edg } \\ \text { orifice }\end{array} \\ \mathrm{x} / \mathrm{H} & \text { Axial Distance-to-Duct Height Ratio } \\ \mathrm{y} & \text { Vertical Coordinate } \\ \mathrm{z} & \text { Lateral Coordinate } \\ \mathrm{C} & (\mathrm{S} / \mathrm{H}) \sqrt{\mathrm{J}} \quad \text { (see Eq. } 1) \\ \mathrm{H} & \text { Duct Height } \\ \mathrm{J} & \text { Momentum-Flux Ratio }\left(\rho_{\mathrm{j}} \mathrm{V}_{\mathrm{j}}^{2}\right) /\left(\rho_{\infty}\right. \\ \mathrm{MR} & \text { Mass-Flow Ratio } \mathrm{m}_{\mathrm{j}} / \mathrm{m}_{\infty} \\ \mathrm{P} & \text { Static Pressure (N/m }) \\ \mathrm{P}_{\mathrm{jet}} & \text { Static Pressure of Jet } \\ \mathrm{P}_{\infty} & \text { Static Pressure of Mainstream } \\ \mathrm{S} & \text { Orifice Spacing } \\ \mathrm{S} / \mathrm{H} & \text { Orifice Spacing-to-Duct Height Ratio } \\ \mathrm{T} & \text { Temperature (K) } \\ \mathrm{T}_{\text {exit }} & \text { Exit Temperature } \\ \mathrm{T}_{\mathrm{jet}} & \text { Temperature of Jet } \\ \mathrm{T}_{\infty} & \text { Temperature of Mainstream } \\ \mathrm{U}_{\infty} & \text { Mainstream Flow Velocity (m/s) } \\ \mathrm{V}_{\mathrm{j}} & \text { Jet Velocity (m/s) }\end{array}$

\footnotetext{
* $\quad$ Project Engineer, Member AIAA

** Vice President/Engineering, Member AIAA

*** Senior Research Engineer, Associate Fellow AIAA
}

1

Copyright (C) 1995 by the American Institute of Aeronautics and Astronautics, Inc. No copyright is asserted in the Lnited States under Title 17, U.S. code. The U. S. Govemment has a rovalty-free license to exercise all rights under the copyright claimed herein for Governmental purposes. All other rights are reserved by the copyright owner. 
$\varepsilon_{\infty} \quad$ Turbulent Energy Dissipation of Mainstream

$\phi_{\mathrm{rb}} \quad$ Rich-Burn Equivalence Ratio

$\phi_{\mathrm{lb}} \quad$ Lean-Burn Equivalence Ratio

$\rho_{\mathrm{j}} \quad$ Density of Jet

$\rho_{\infty} \quad$ Density of Mainstream

\section{Introduction}

In recent years, the concern over the environmental impact of aircraft gas turbine technology has steadily increased. The need for the reduction of both carbon monoxide $(\mathrm{CO})$ and oxides of nitrogen $\left(\mathrm{NO}_{\mathrm{x}}\right)$ is quickly becoming a very sensitive issue. Past advancements to aircraft gas turbine engines have focused on increasing the overall thermodynamic cycle efficiency by implementing increases in pressure and temperatures. The increases tend to have an adverse effect on $\mathrm{NO}_{x}$ emission levels, necessitating the development of new ways of controlling $\mathrm{NO}_{\mathrm{x}}$.

In order to improve the emission signatures of combustors, the industry has departed from the standard single axial staged combustion to pursue staged burning. One such concept being evaluated both experimentally and numerically is the Rich-burn/Quickmix/Lean-burn (RQL) combustor ${ }^{1}$. This combustor utilizes the staged burning concept in which the primary zone is designed to operate fuel rich. ${ }^{2}$ The combustion products high in carbon monoxide concentration enter the quick-mix section where mixing is initiated with bypass air. The combustion process is then completed in the lean-burn region.

To achieve the low emission goals set for RQL combustors, high importance must be placed on attaining rapid and uniform mixing in the quick-mix section. Recent experimental and numerical studies have been completed that investigated and assessed improved mixing concepts ${ }^{3-18}$

\section{Background}

For quite some time the importance of research on jet mixing in a confined crossflow has been recognized as having a significant impact on a variety of practical applications. Within gas turbine technology, jet mixing plays a particularly important role in the dilution zone of the combustor. The dilution zone is the aft zone where the products of combustion are mixed with air to produce a temperature profile acceptable to the turbine. ${ }^{19-21}$

As of late, many studies have been conducted relative to jet mixing in gas turbine applications ${ }^{22-27}$. These studies have concentrated on both rectangular and cylindrical geometric configurations. The results of these studies have identified two significant design parameters that influence the mixing pattern: 1) jet-tomainstream momentum-flux ratio (J) and 2) orifice spacing-to-duct height ratio $(\mathrm{S} / \mathrm{H})$. Optimum mixing relationships were determined to be a function of the product of $\mathrm{S} / \mathrm{H}$ and square root of $\mathrm{J}$ for the range of conditions tested and analyzed ${ }^{19}$ :

$$
\mathrm{C}=(\mathrm{S} / \mathrm{H}) \sqrt{\mathrm{J}}
$$

These studies summarized in Ref. 19 examined both two-sided and single-sided injection in rectangular geometries. Table 1 shows the constants derived from these studies. The optimum $\mathrm{C}$ value was shown to be 1.25 for inline, two-sided injection, while single-sided injection produced a $\mathrm{C}$ value of 2.5 . It was determined that the best mixing occurred when the dilution jet reached a penetration level of $1 / 4$ duct height for twosided injection. Previous dilution jet work focused on conditions where the jet-to-mainstream mass-flow levels were less than 0.50. More recent numerical and experimental research has examined the effect of increased mass-flow ratios, more typical of $R Q L$ combustors (i.e. $M R>2.0$ ). The results for $M R>2.0$ have concluded that the $\mathrm{C}$ value is about twice $(2.5 \mathrm{vs}$. 
$1.25)$ that of the lower mass-flow ratio cases for twosided, rectangular configurations.

Presently, the design of the mixing section is pursuing two options. The first employs a full annular geometry, while the second consists of a can mixing section. The basic questions that needed to be addressed were: 1) is there an inherent difference between the way can and annular configurations mix, 2) does one of these produce higher $\mathrm{NO}_{x}$ than the other, and 3) can one be optimized based on knowledge of the other? Although many factors (i.e. liner cooling considerations, structural requirements, etc.,) will play a role in the decision making process, the input of geometry on emission signature is an equally important factor. This study sought to address these issues by a systematic computational analysis. A complete description of the work follows.

\section{CFD Code}

The approach in this study was to perform 3-D numerical calculations on generic geometry sections. The CFD code named CFD-ACE ${ }^{28}$ was used to perform the computations. The basic capabilities/methodologies in CFD-ACE include:

(1) co-located, fully implicit and strongly conservative finite volume formulation;

(2) solution of two- and three-dimensional NavierStokes equations for incompressible and compressible flows;

(3) non-orthogonal curvilinear coordinates;

(4) multi-block grid topology;

(5) upwind, central (with damping), second order upwind and Osher-Chakravarthy differencing schemes;

(6) standard ${ }^{29}$, extended ${ }^{30}$, RNG and low Reynolds number ${ }^{31} \mathrm{k}-\varepsilon$ turbulence models;

(7) instantaneous, one-step, two-step, and fourstep heat release and emission combustion models;
(8) spray models including trajectory, vaporization, etc.; and

(9) pressure-based solution algorithms including SIMPLE and a variant of SIMPLEC.

\section{Details of Numerical Calculations}

The analysis was divided up into two parametric studies. The first parametric study focused on the annular geometries, while the second concentrated on the can geometries. A schematic of the annular geometry is shown in Figure 1. The inner radius of the annulus measured $0.3896 \mathrm{~m}$ with the outer radius measuring $0.4404 \mathrm{~m}$. The height of the mixing section was $0.0508 \mathrm{~m}$. The computation domain extended $0.152 \mathrm{~m}$ from the leading edge of the orifice $(x / H=3.0)$. The walls were modeled as being $0.0064 \mathrm{~m}$ thick. Above each orifice a plenum $0.076 \mathrm{~m}$ long was constructed. The annular model consisted of two-sided injection from the top and bottom orifices into the mainstream crossflow.

A constant shape orifice was selected for use in both of the parametric studies. The orifice was a slot with rounded ends and had a 2:1 length-to-width aspect ratio. The selection of the 2:1 rounded slot was made to ensure enough orifices would be able to fit on the ID of the annular configuration for an underpenetrated jet configuration. The 2:1 rounded slots were aligned with the long dimension in the direction of the mainstream flow.

The can configurations were made comparable to the annular configuration by making the can cross-sectional area equal to a one-nozzle sector of the annular geometry. Thus for a 24-nozzle annular combustor, the diameter for the equivalent-area can geometry was $0.084 \mathrm{~m}$. A schematic of the can geometry is presented in Figure 2.

To enhance the computational efficiency of the numerical calculations, only one set of orifices (top and 
bottom) was modeled. Similarly, only one orifice was modeled for the can geometry. For the annular geometry, the orifices were located on the inner and outer diameter in the same axial plane, and inline in the transverse direction. The transverse calculation domain extended from midplane to midplane between the jets' centerlines. Periodic boundary conditions were assumed on the transverse boundaries. For the can geometry, a single orifice was located on the outer liner with periodic boundary conditions being specified on the transverse boundaries.

Four parametric cases were analyzed for the annular geometry, while six cases were performed for the can geometry. For each case, the orifice spacing, S/H, was varied parametrically while maintaining all other design variables constant. Note that as the orifice spacing was varied, the size of the orifice was changed to maintain constant flow area. The intent of this method was to optimize each geometry based on the lowest emission signature. A full range of jet penetration levels was studied, including under, optimum, and over-penetrating cases.

Tables 2 and 3 show the geometry specifics for the can and annular cases, respectively. The six can cases are designated C1-C6. These cases correspond to 5, 6, 7, 8, 10, and 12 holes on the can liner. For the annular analysis, the cases are labeled as AN1-AN4. Test case AN1 corresponds to 3 orifices on the inner and outer diameter ( 6 orifices in a one-nozzle sector) and continues to 6 orifices on ID\&OD (12 orifices in the nozzle sector). Since the areas of the annular 15 degree sector and the can are set equal, the orifices are identical when there are the same number of orifices in the can and annular configurations (e.g. AN1 \& C2 have identical orifices).

To determine the jet-to-mainstream momentum-flux ratio $(\mathrm{J})$, the jet velocity had to be calculated. The pressure drop across the orifice was determined by using the total pressure at the plenum inlet and the mass- averaged static pressure across the orifice exit. It should be mentioned that the static pressure and radial velocity at the orifice exit were highly non-uniform in the axial direction. From this pressure drop, the velocity of the jet at the orifice exit was calculated, as well as the orifice discharge coefficient $\left(C_{d}\right)$. The $C_{d}$ for the orifice was calculated to be 0.685 . Using the jet velocity based on the pressure drop, the momentum-flux ratio was calculated to be 30 .

The turbulence boundary conditions, $\mathrm{k} \& \varepsilon$, were determined in the following manner. For the mainstream (rich-burn) flow, the turbulence parameters were determined from unreported CFD calculations of the rich-burn section. For the jets, the turbulence levels were determined by the CFD analysis as the flow proceeded from the plenums into the orifices. The inlet turbulence into the plenum had no effect on the turbulence through the orifices; hence the inlet turbulence to the plenums were set at nominal values.

The flow conditions of the mainstream and jets were:

$$
\begin{gathered}
\underline{\text { Mainstream }} \quad \underline{\text { Jets }} \\
\begin{array}{l}
\mathrm{U}_{\infty}=43.5 \mathrm{~m} / \mathrm{s} \quad \mathrm{P}_{\text {jet }}=9.72 \times 10^{5} \mathrm{~N} / \mathrm{m}^{2} \\
\mathrm{~T}_{\infty}=2035 \mathrm{~K} \quad \mathrm{~T}_{\text {jet }}=777 \mathrm{~K} \\
\mathrm{P}_{\infty}=9.72 \times 10^{5} \mathrm{~N} / \mathrm{m}^{2} \\
\mathrm{k}_{\infty}=118.0 \mathrm{~m}^{2} / \mathrm{sec}^{2} \\
\varepsilon_{\infty}=5.4 \times 10^{4} \mathrm{~m}^{2} / \mathrm{sec}^{3} \\
\mathrm{~J}=30 \\
\mathrm{~m}_{\mathrm{j}} / \mathrm{m}_{\infty}=3.20 \\
\mathrm{~T}_{\text {exit }}=1755 \mathrm{~K} \\
\phi_{\mathrm{rb}}=2.0 \\
\phi_{\text {lb }}=0.425
\end{array}
\end{gathered}
$$

\section{Grids}

The computational mesh was created using CFD$\mathrm{GEOM}^{32}$, an interactive three-dimensional geometry modeling and mesh generation software. A typical 
annular case consisted of approximately 63,000 cells. The breakdown of the cell distribution was as follows:

Top and Bottom Plenums 42x 10x28 [x,y,z direction] Mixing Region $77 \times 20 \times 28$

The can grid was separated into:

$\begin{array}{ll}\text { Top Plenum } & 42 \times 10 \times 28 \\ \text { Mixing Region } & 77 \times 20 \times 28\end{array}$

The orifices were composed of $28 \times 14$ uniformly distributed cells. The orifice was modeled with 5 cells in the vertical direction to represent the wall thickness of $0.0064 \mathrm{~m}$. A typical annular grid is shown in Figure 3. The grid upstream and downstream of the orifice region was expanded/contracted so that each cell adjacent to the orifice region matched the cell size in the slot region. The cells in the vertical direction were compressed in the vicinity of the wall to more accurately capture any wall effects.

\section{Numerics \& Models}

The following conservation equations were solved: u momentum, $v$ momentum, $w$ momentum, mass (pressure correction), turbulent kinetic energy (k), turbulent energy dissipation $(\varepsilon)$, enthalpy (h), and mixture fraction (f). The convective fluxes were calculated using upwind differencing, and the diffusive fluxes were calculated using central differencing. The standard $\mathrm{k}-\varepsilon$ turbulence model was employed and conventional wall functions were used. The walls were assumed to be adiabatic. The turbulent Schmidt and Prandtl numbers were set to 0.5 . A fast chemistry (instantaneous) model was assumed. Equilibrium products were also assumed. The use of a fast chemistry model was based on LSENS ${ }^{33}$ calculations using a 63-step, 33 species reaction model; the chemical reaction times were small compared to flow times at the conditions being studied.

\section{Convergence}

All error residuals were reduced at least 4 orders of magnitude, and continuity was conserved in each axial plane to the fifth decimal. A converged solution required approximately 8-12 CPU hours on a CRAY C90 computer.

\section{Rich-Burn Inlet Conditions}

The inlet to the rich-burn section was assumed to be premixed fuel and air. The fuel used in this analysis was $\mathrm{C}_{10} \mathrm{H}_{19}$, representative of Jet $\mathrm{A}$ fuel. The inlet premixed equivalence ratio $\left(\phi_{\mathrm{rb}}\right)$ was specified to 2.0 . As the inlet flow entered the first cell of the computational domain, it burned immediately to equilibrium products. The resulting downstream flow was representative of rich-burn conditions entering the quench zone.

\section{Data Postprocessing}

Graphics postprocessing was performed using CFDVIEW $^{34-35}$, an interactive graphical visualization tool. The $\mathrm{NO}_{\mathrm{x}}$ results were calculated using a post-processing tool named CFD-POST. ${ }^{36}$ Using the equilibrium species calculated in the CFD-ACE solution, $\mathrm{NO}_{x}$ was calculated using an extended Zeldovich thermal $\mathrm{NO}_{x}$ model shown below in equation (2). ${ }^{37,38}$ The effect of turbulent fluctuations was included by using a prescribed, beta function pdf.

$$
\frac{d(N O)}{d t}=2 k_{1}(O)\left(N_{2}\right) \frac{1-\frac{(N O)^{2}}{K\left(O_{2}\right)\left(N_{2}\right)}}{1+\frac{k_{\cdot 1}(N O)}{\left[k_{2}\left(\mathrm{O}_{2}\right)+k_{3}(\mathrm{OH})\right]}}
$$

where, $K=\left(k_{1} / k_{-1}\right)\left(k_{2} / k_{-2}\right)$ is the equilibrium constant for the reaction between $\mathrm{N}_{2}$ and $\mathrm{O}_{2}$. 


\section{Results and Discussion}

The results for the parametric cases are presented using three variables: equivalence ratio, temperature, and $\mathrm{NO}_{\mathrm{x}}$ production.

\section{Annular Geometry}

The effect of orifice spacing on jet penetration is presented in Figures 4 and 5. Plotted in Figure 4 are the temperature contours in a lateral plane through the orifice centerline. Similarly, the equivalence ratios are shown in Figure 5. The 6ID/6OD configuration (case AN4 in Table 3) is clearly underpenetrated, represented by a core of mainstream fluid passing through the center of the duct. In contrast, the $3 \mathrm{ID} / 3 \mathrm{OD}$ case (AN1 in Table 3) exhibits overpenetration of the jet; the mainstream flow is deflected to the outer wall. This is seen by the higher temperature along the $\mathrm{OD}$ and ID wall for the 3ID/3OD (AN1) case. The 4ID/4OD (AN2 in Table 3) and 5ID/5OD (AN3 in Table 3) configurations exhibit near-optimum characteristics. The jet penetrates to approximately $1 / 4$ duct height for these cases. From the equivalence ratio contours shown in Figure 5, the 5ID/5OD (AN3) appears to show the most uniform downstream mixing characteristics at the exit.

Shown in Figure 6 are axial planes at $\mathrm{x} / \mathrm{H}=1.0$ for temperature and equivalence ratios. The high temperatures along the wall in the $3 \mathrm{ID} / 3 \mathrm{OD}$ (AN1) case indicate the over-penetrating jets, while the 6ID/6OD (AN4) case shows the hot mainstream flow in the duct center typical of under-penetrating jets. Note that the OD near-wall temperature is hotter than the ID near-wall temperature for each case. This occurs because the orifice spacing is greater for the OD liner, resulting in more mainstream (rich-burn) flow passing between the jets.

Figure 7 shows the $\mathrm{NO}_{\mathrm{x}}$ production for the annular parametric cases. $\mathrm{NO}_{\mathrm{x}}$ is mainly produced in regions where there is near-stoichiometric temperature and oxygen available. The high $\mathrm{NO}_{x}$ production along the OD wall in the 3ID/3OD (AN1) case results from excessive mainstream flow passing between the jets and then mixing with the jet airflow. When the jets underpenetrate, as in the 6ID/6OD (AN4) case, excessive $\mathrm{NO}_{\mathrm{x}}$ is produced along the center of the duct. The lowest amount of $\mathrm{NO}_{\mathrm{x}}$ production occurs when the jets have optimum penetration, i.e., 4ID/4OD (AN2) case and the 5ID/5OD (AN3) case.

\section{Can Geometry}

Figures 8 and 9 show the corresponding temperature and equivalence ratio contour plots for the can parametric. Note, only a single jet is shown for the can configurations; the bottom of the plot represents the can centerline. As seen in the previous annular results, an increase in the number of orifices translates into a corresponding decrease in jet penetration levels. It can be seen in Figures 8 and 9 that the jets are overpenetrated for the 5 orifice case ( $\mathrm{C} 1$ in Table 2), underpenetrated for the 8 orifice case ( $\mathrm{C} 4$ in Table 2), and near optimally penetrated for the 6 ( $\mathrm{C} 2$ in Table 2) and 7 ( $\mathrm{C} 3$ in Table 2$)$ orifice cases.

Figure 10 shows the axial planes at $x / R=1.0$ for temperature and equivalence ratios. It can be seen that stoichiometric burning occurs near the liner for the 5 orifice case (C1), near the centerline for the 8 orifice case (C4), and near both the liner and centerline for the 6 (C2) and 7 orifice (C3) cases. Once again, the 6 (C2) and 7 orifice (C3) cases appear to be near optimum in terms of jet penetration and mixing.

Figure 11 presents the $\mathrm{NO}_{\mathrm{x}}$ production for the can cases. By comparing Figure 11 with Figure 8, it can be seen that the highest $\mathrm{NO}_{\mathrm{x}}$ production locations correspond to areas of near stoichiometric flame temperatures. For the overpenetrating, 5 orifice case (C1), most of the $\mathrm{NO}_{\mathrm{x}}$ is produced next to the liner. For the underpenetrating, 8 orifice case $(\mathrm{C} 4)$, there is almost no $\mathrm{NO}_{\mathrm{x}}$ being formed on the liner; all of the $\mathrm{NO}_{x}$ is formed on the centerline. 
Emissions

To effectively quantify the emissions results, both the $\mathrm{NO}_{\mathrm{x}}$ and $\mathrm{CO}$ signature must be considered in the analysis. In some cases low $\mathrm{NO}_{\mathrm{x}}$ levels can be predicted, but significant concentrations of $\mathrm{CO}$ can still be present in the gas flow. High levels of $\mathrm{CO}$ translates into combustion inefficiency, and is undesirable. Low $\mathrm{NO}_{\mathrm{x}}$ that is achieved due to combustion inefficiency is not an acceptable design.

Figure 12 presents normalized $\mathrm{NO}_{\mathrm{x}}$ as a function of $\mathrm{x} / \mathrm{H}$ for the annular cases. Up to $\mathrm{x} / \mathrm{H}=0.5$, all configurations produce a comparable amount of $\mathrm{NO}_{\mathrm{x}}$. $\mathrm{NO}_{\mathrm{x}}$ continues to be produced all the way to $\mathrm{x} / \mathrm{H}$ of 3.0 for the 3ID/3OD (AN1) and 6ID/6OD (AN4) cases, and will continue being produced downstream of $\mathrm{x} / \mathrm{H}$ of 3.0 due to lack of mixing. Both the 4ID/4OD (AN2) and 5ID/5OD (AN3) cases show the $\mathrm{NO}_{\mathrm{x}}$ leveling off by $x / H$ of 3.0. This "leveling off" is an indication of good mixing. At the mixed-out temperature of these cases $(1755 \mathrm{~K})$, no additional $\mathrm{NO}_{\mathrm{x}}$ should be formed once near-complete mixing has occurred. If there are pockets of higher equivalence ratio (and thus higher temperatures), $\mathrm{NO}_{\mathrm{x}}$ will continue to be formed, as shown by the 3ID/3OD (AN1) and 6ID/6OD (AN4) cases. Figure 13 shows contour plots of both the equivalence ratios and temperatures for the annular parametric at $x / H=3.0$. These contour plots show that the 4ID/4OD (AN2) and 5ID/5OD (AN3) cases have the most complete mixing, while the 3ID/3OD (AN1) and 6ID/6OD (AN4) cases still exhibit significant radial variations.

Figure 14 presents a plot of $\mathrm{CO}$ emissions index (EI) versus $\mathrm{x} / \mathrm{H}$ for each of the annular cases. Note that the CFD analysis assumes a fast chemistry approximation, and any $\mathrm{CO}$ that is present in the flowfield is a direct result of lack of mixing. Each CO EI figure is divided into two graphs. The first graph shows the overall $\mathrm{CO}$ EI levels for the parametric cases. The inserted graph shows an enlarged view of the lower end of the CO EI scale. Equilibrium $\mathrm{CO}$ EI for $\phi_{1 b}=0.425$ is 2 , and a combustion efficiency of $99.5 \%$ corresponds to a CO EI of 20. A horizontal line is shown on the graphs to represent the $99.5 \%$ combustion efficiency level. All the cases reach a CO EI of 20 well before reaching the exit $(x / H>3.0)$. Of the four cases, the 3ID/3OD (AN1) has the highest $\mathrm{CO}$, not falling below 20 until $\mathrm{x} / \mathrm{H}$ of 1.8 .

Figures 15 and 16 show the normalized $\mathrm{NO}_{\mathrm{x}}$ and $\mathrm{CO}$ $\mathrm{EI}$ as a function of $\mathrm{x} / \mathrm{R}$ for the can parametric. The $\mathrm{NO}_{\mathrm{x}}$ curves all have positive slopes at $x / R>3.0$ indicating ongoing $\mathrm{NO}_{\mathrm{x}}$ production. Only the $6(\mathrm{C} 2)$ and $7(\mathrm{C} 3)$ orifice cases are starting to level off. The $\mathrm{CO}$ curves shown in Figure 16 take a much longer axial distance to reach the $99.5 \%$ combustion efficiency level than the annular cases $(x / R=2.0-2.5$-can vs. $x / H=1.5$-annular $)$, and even then only the 5 (C1), 6 (C2), and 7 (C3) orifice cases attain the $99.5 \%$ level. For the other cases the positive slopes of the $\mathrm{NO}_{\mathrm{x}}$ curves and the presence of $\mathrm{CO}$ remaining in the flowfield suggest the need of a longer lean-burn section to achieve the necessary combustion efficiency.

Based on the emission curves, the optimum configurations are the 5ID/5OD (AN3) case for the annular geometry, and the 7 orifice case (C3) for the can geometry. These two configurations were selected as being optimum because 1.) they showed the lowest overall $\mathrm{NO}_{\mathrm{x}}$ at the exit plane, and 2.) reached a combustion efficiency of $99.5 \%$ before the end of the mixing section. A comparison of the two optimum configurations is shown in Figure 17. Note the $x / R_{\text {eq }}$ used for the annular geometry is based on the radius of an equal area can. From Figure 17, both configurations show similar trends of $\mathrm{NO}_{\mathrm{x}}$ production. The $\mathrm{NO}_{\mathrm{x}}$ production in the first $x / R=2.25$ is approximately the same. Towards $x / R=4.0$, the annular geometry shows a slightly lower value of $\mathrm{NO}_{\mathrm{x}}$. In addition, both curves are "leveling off", indicating good overall mixing and no $\mathrm{NO}_{\mathrm{x}}$ production (i.e. no significant $\mathrm{NO}_{\mathrm{x}}$ contribution farther downstream). Therefore, from a design standpoint, there is no significant emission 
advantage gained by the selection of either the annular or can geometry.

\section{Design Correlation Constant for Annular and Can Configuration}

The last columns of Tables $2 \& 3$ show the optimum mixing design correlation constants based on the equation, $\mathrm{C}=(\mathrm{S} / \mathrm{H}) \sqrt{\mathrm{J}}$.

For the can cases (Table 2), the constant were determined using two different spacing methods;

1. Orifice spacing at the $O D$

2. Orifice spacing at a radius corresponding to equal flow areas in the can

These methods are illustrated at the bottom of Table 2 . Similarly, these methods exist for the annular geometry. For the annular cases, the constants were calculated based on orifice spacing at the ID and OD (Method 1), and equivalent area spacing (Method 2). Method 2 has been reported to be the appropriate method for both can and annular configurations. ${ }^{19}$

Based on the emission results, the optimum configuration for the annular geometry is the 5ID/5OD (AN3) case. The design constant for this case is 2.35. This $\mathrm{C}$ value is consistent with results from previously performed high jet-to-mainstream mass-flow ratio (MR $>2.0$ ) analyses. It is about twice the value reported for low MR's $(<0.5)$.

The can emission results indicate that the 7 orifice case (C3) has the best emission signature. Using the equal area approach, the $\mathrm{C}$ constant is 3.5 , or $40 \%$ higher than that reported for mixing at lower MR $(<0.5)$.

\section{Conclusions}

A CFD parametric analysis was performed on transverse jets injected into both annular and can confined crossflow. The slot spacing was systematically varied while maintaining all other design variables constant. Optimum configurations were determined based on jet penetration, and $\mathrm{NO}_{x}$ and $\mathrm{CO}$ emissions. The conclusions that can be drawn are as follows;

1. Optimum annular and can geometries have similar emission characteristics at the end of a mixing section and lean-burn section $(\mathrm{x} / \mathrm{H}=3.0)$ as long as jet penetration/mixing is optimized.

2. For the MR of 3.2 evaluated in this study, the design correlation constant $[\mathrm{C}=(\mathrm{S} / \mathrm{H}) \sqrt{\mathrm{J}}]$ was 2.35 for the annulus and 3.5 for the can. The value for the annulus is about twice the value for low MR's (< 0.5 ). The value for the can is about $40 \%$ higher than that for the low MR.

\section{Acknowledgement}

This work was supported by NASA Contract NAS325967 , and NAS computer time was provided by NASA Lewis Research Center. The authors would like to thank Mr. Gary Hufford and Dr. Bhavin Patel for their expertise and help in the use of CFD-GEOM. In addition, thanks are also extended to Dr. Andy Leonard and the CFD-ACE development and support staff for their assistance in using the combustion model. Last but not least, thanks are given to Ms. Marni Kent for preparing this typescript.

\section{References}

1. R. J. Shaw, "Engine Technology Challenges for a 21st Century High Speed Civil Transport," AIAA Tenth International Symposium on Air Breathing Engines, September 1-6, 1991 (Also NASA TM 104363).

2. S. A. Mosier and R. M. Pierce, "Advanced Combustion Systems for Stationary Gas Turbine Engines," Vol. 1, EPA Contract 68-02-2136, 1980 . 
3. C. E. Smith, M. V. Talpallikar, and J. D. Holdeman, "A CFD Study of Jet Mixing in Reduced Flow Areas for Lower Combustor Emissions," AIAA 91-2460, June, 1991 (Also NASA TM 104411).

4. A. Vranos, D. S. Liscinsky, B. True, and J. D. Holdeman, "Experimental Study of Cross-Stream Mixing in a Cylindrical Duct," AIAA 91-2459, June, 1991 (Also NASA TM 105180).

5. M. V. Talpallikar, C. E. Smith, M. C. Lai, and J. D. Holdeman, "CFD Analysis of Jet Mixing in Low $\mathrm{NO}_{\mathrm{x}}$ Flametube Combustors," ASME Paper 91-GT-217, Vol. 114, pp. 416-424, ASME Transactions, Journal of Engineering for Gas Turbines and Power, 1992 (Also NASA TM 104466).

6. G. W. Howe, Z. Li, T. I.-P. Shih, and H. L. Nguyen, "Simulation of Mixing in the Quick Quench Region of a Rich Burn-Quick QuenchLean Burn Combustor," AIAA 91-0410, 1991.

7. M. S. Hatch, W. A. Sowa, G. S. Samuelsen, and J.D. Holdeman, "Jet Mixing Into a Heated Cross Flow in a Cylindrical Duct: Influence of Geometry and Flow Variations," Accepted for publication in Journal of Propulsion and Power. (See also AIAA 92-0773, January 1992 and NASA TM 105390).

8. D. B. Bain, C. E. Smith, and J. D. Holdeman, "CFD Mixing Analysis of Jets Injected from Straight and Slanted Slots into Confined Crossflow in Rectangular Ducts," AIAA 923087, (Also NASA TM 105699).

9. D. S. Liscinsky, B. True, A. Vranos, and J. D. Holdeman, "Experimental Study of Cross-Stream Mixing in a Rectangular Duct," AIAA 92-3090, (Also NASA TM 106194).
10. M. S. Hatch, W. A. Sowa, G. S. Samuelsen, and J. D. Holdeman, "Influence of Geometry and Flow Variations on NO Formation in the Quick Mixer of a Staged Combustor," Accepted for publication in Journal of Engineering for Gas Turbine and Power, (See also NASA TM 105639, July 1992).

11. V. L. Oechsle, H. C. Mongia, and J. D. Holdeman, "A Parametric Numerical Study of Mixing in a Cylindrical Duct," AIAA 92-3088, (Also NASA TM 105695).

12. G. Zhu and M.-C. Lai, "A Parametric Study of Penetration and Mixing of Radial Jets in NeckedDown Cylindrical Crossflow," AIAA 92-3091.

13. J. T. Kroll, W. A. Sowa, G. S. Samuelsen, and J. D. Holdeman, "Optimization of Circular Orifice Jets Mixing into a Heated Crossflow in a Cylindrical Duct," AIAA 93-0249, (Also NASA TM 105984).

14. D. S. Liscinsky, A. Vranos, and R. P. Lohmann, "Experimental Study of Crossflow Mixing in Cylindrical and Rectangular Ducts," NASA CR 187141, March 1993.

15. Th. Doerr and D. K. Hennecke, "The Mixing Process in the Quenching Zone of the Rich-Lean Combustion Concept," AGARD $81^{\text {st }}$ Symposium on Fuels and Combustion Technology for Advanced Aircraft Engines, Colleferro, NR Rome, Italy, May 10-14, 1993.

16. D. S. Liscinsky, B. True, and J. D. Holdeman, "An Experimental Study of Crossflow Jet Mixing in Rectangular Ducts," AIAA-93-2037 (also TM 106152).

17. D. B. Bain, C. E. Smith, and J. D. Holdeman, "CFD Mixing Analysis of Axially Opposed Rows of Jets Injected in Confined Crossflow," Accepted for publication in Journal of Propulsion and Power, (See also AIAA Paper 93-2044 and NASA TM 106179). 
18. V. L. Oechsle, H. C. Mongia, and J. D Holdeman, "An Analytical Study of Jet Mixing in a Cylindrical Duct", AIAA 93-2043, (Also NASA TM 106181).

19. J. D. Holdeman, "Mixing of Multiple Jets with a Confined Subsonic Crossflow," Progress in Energy and Combustion Sciences, Vol. 19, pp. 31-70, 1993. (also NASA TM 104412, 1991 and AIAA 91-2458, 1991).

20. J. D. Holdeman, R. Srinivasan, R. Reynolds, and C. D. White, "Studies of the Effects of Curvature on Dilution Jet Mixing, Joumal Propulsion and Power, Vol. 8, No. 1, p. 209, 1992. (Also, AIAA Paper 87-1953; NASA TM -89878 and AIAA Paper 88-3180; NASA TM-00896).

21. D. S. Crocker and C. E. Smith, "Numerical Investigation of Enhanced Dilution Zone Mixing in a Reverse Flow Gas Turbine Combustor," ASME 93-GT-129, 1993.

22. D.B.Bain, C.E. Smith, and J.D. Holdeman, (1994). "CFD Assessment of Orifice Aspect Ratio and Mass Flow Ratio on Jet Mixing in Rectangular Ducts. AIAA Paper 94-0218 (also NASA TM 106477).

23. D.S. Liscinsky, B. True, and J.D. Holdeman, (1994) "Mixing Characteristics of Directly Opposed Rows of Jets Injected Normal to a Crossflow in a Rectangular Ducts. AIAA Paper 94-0217 (also NASA TM 106477).

24. V.L. Oechsle, H.C. Mongia, and J.D. Holdeman, (1994). "Comparison of the Mixing Calculations of Reacting and Non-Reacting Flows in a Cylindrical Duct." AIAA Paper 940865 (also NASA TM 106436).

25. W.A. Sowa, J.T. Kroll, G.S. Samuelsen, and J.D. Holdeman, (1994). "Optimization of Orifice Geometry for Crossflow Mixing in a Cylindrical Duct." AIAA Paper 94-0219 (also NASA TM 106436)
26. D.S. Liscinsky, B. True, and J.D. Holdeman, (1995). "Crossflow Mixing of Noncircular Jets. Accepted for publication in Joumal of Propulsion and Power, (see also AIAA Paper 95-0732 and NASA TM 106865).

27. V.L. Oechsle and J.D. Holdeman, (1995). Numerical Mixing Calculations of Confined Reacting Jet Flows in a Cylindrical Duct. AIAA Paper 95-0733 (also NASA TM 106736).

28. S. F. Owens, "CFD-ACE: Command Language Reference Manual," CFD Research Corporation, Huntsville, AL, CFDRC Report GR-92-6, 1992.

29. B. E. Launder and D. B. Spalding, "The Numerical Computation of Turbulent Flows," Computer Methods in Applied Mechanics and Engineering, Vol. 3, pp. 269-289, 1974.

30. Y. S. Chen and S. W. Kim, "Computation of Turbulent Flows Using an Extended $k-\varepsilon$ Turbulence Closure Model," NASA CR-179204, 1987.

31. K. Y. Chien, "Predictions of Channel and Boundary-Layer Flows with a Low-Reynolds Number-Turbulence Model," AIAA Journal, Vol. 23, No. 2, 1985.

32. CFD-GEOM User Manual, Version 1.3, March 1995.

33. K. Radhakrishnan and D. A. Bittker, LSENS, A General Chemical Kinetics and Sensitivity Analysis Code for Gas-Phase Reactions: User's Guide, NASA Technical Memorandum 105851, January 1993.

34. V. J. Harrand, "CFD VIEW: A 3D Computer Graphics Software; Volume 1: Technical Manual," August 1992.

35. V. J. Harrand, "CFD VIEW: A 3D Computer Graphics Software; Volume 2: User's Manual," August 1, 1992.

36. CFD-POST User Manual, Version 1.06, July 1994.

37. W. Bartok and A. F. Sarofim, Fossil Fuel Combustion, New York, p. 233, 1991. 
38. D. G. Nicol, R. C. Steele, N. M. Marinov, and P. C. Malte, "The Importance of the Nitrous Oxide Pathway to $\mathrm{NO}_{x}$ in Lean-Pre-Mixed Combustion," ASME Paper 93-GT-342, ASME Transactions, Cincinnati, May 1993. 
Table 1. Spacing and Momentum-Flux

Ratio Relationships

\begin{tabular}{|l|c|}
\hline Configuration & $\mathrm{C}=(\mathrm{S} / \mathrm{H}) \sqrt{(\mathrm{J})}$ \\
\hline Single-side injection: & $<1.25$ \\
Under-penetration & 2.5 \\
Optimum & $>5.0$ \\
Over-penetration & \\
& \\
Opposed rows of jets: & 1.25 \\
In-line optimum & 5.0 \\
Staggered optimum & \\
\hline
\end{tabular}




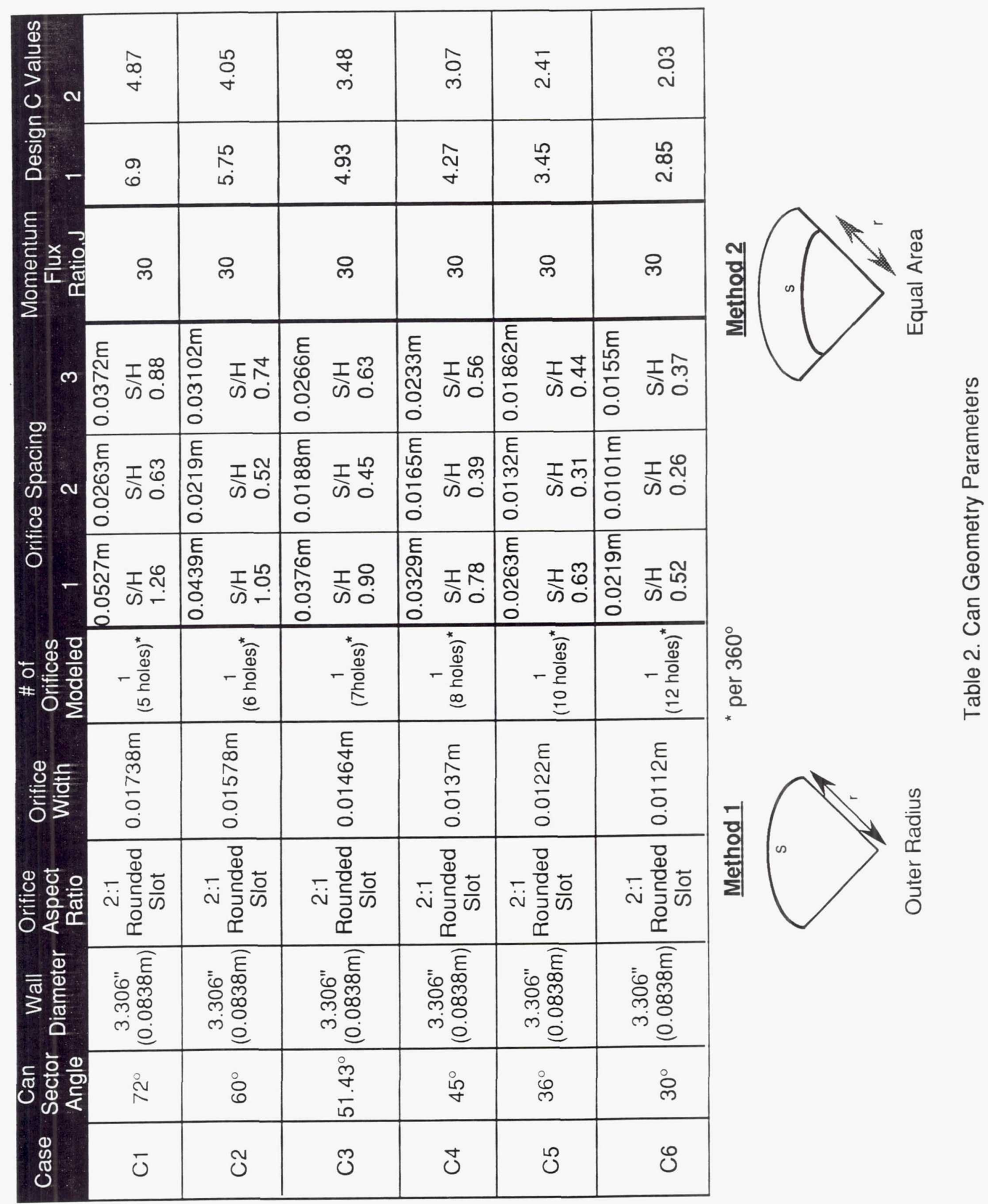




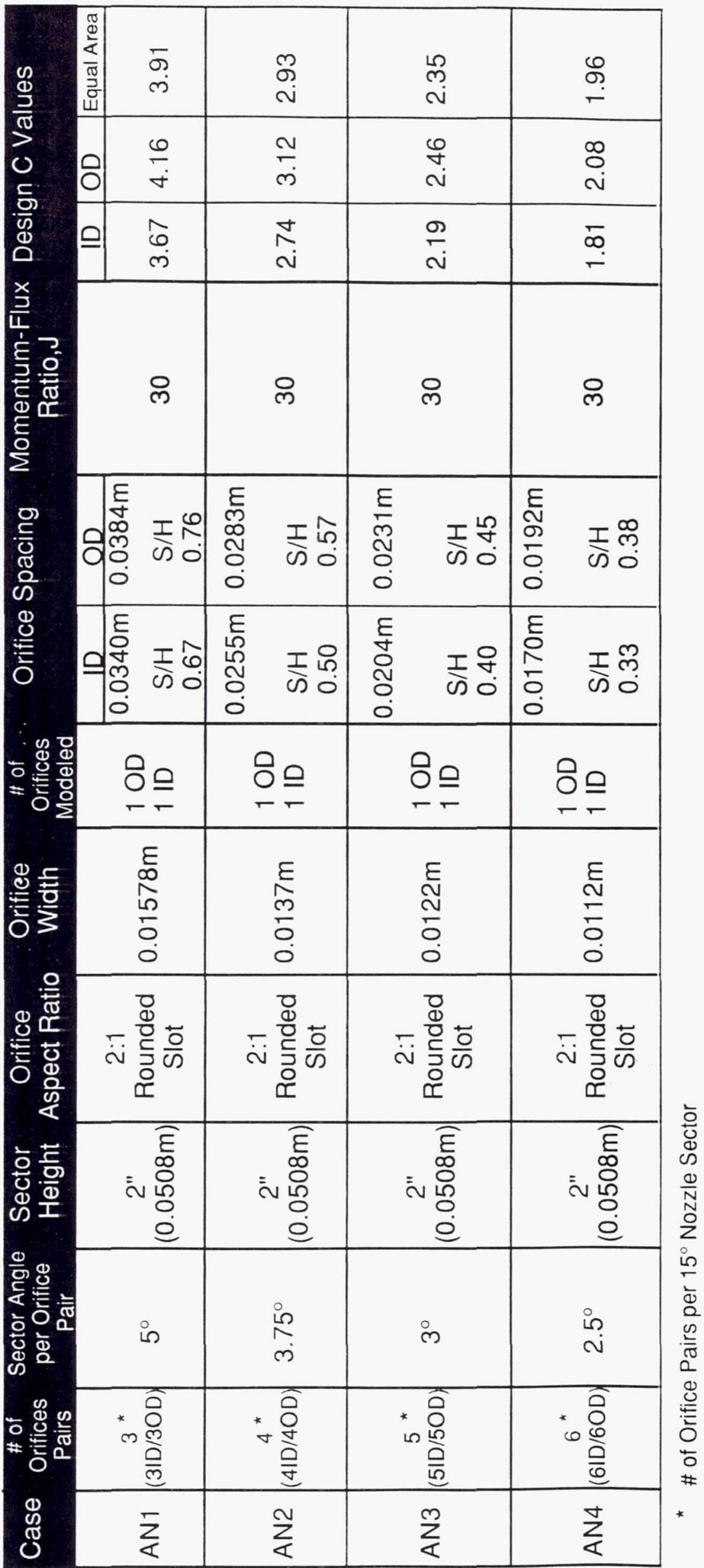

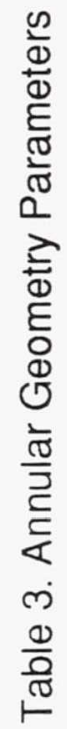




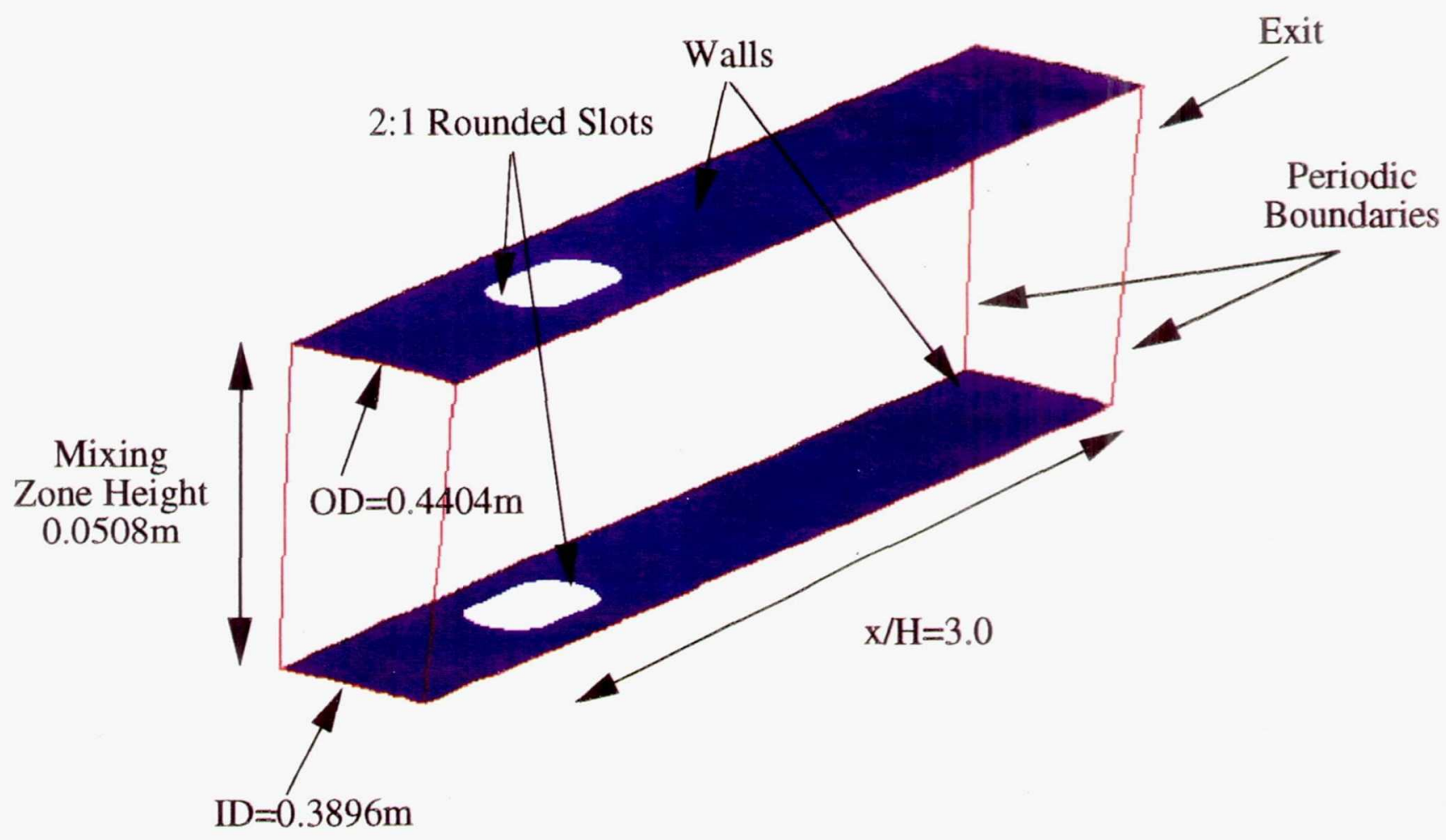

Figure 1. Schematic of the Annular Geometry

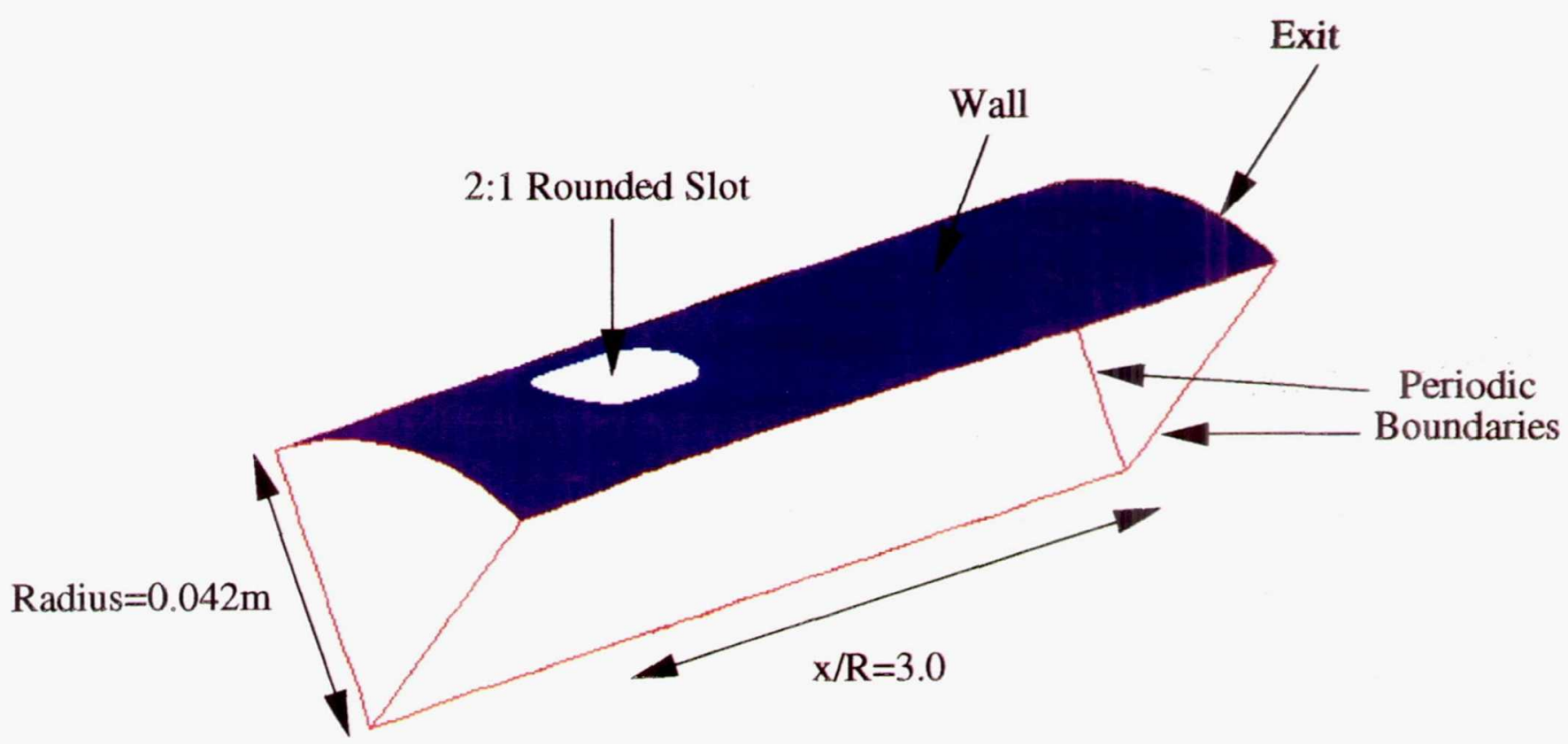

Figure 2. Schematic of the Can Geometry 
Page intentionally left blank 


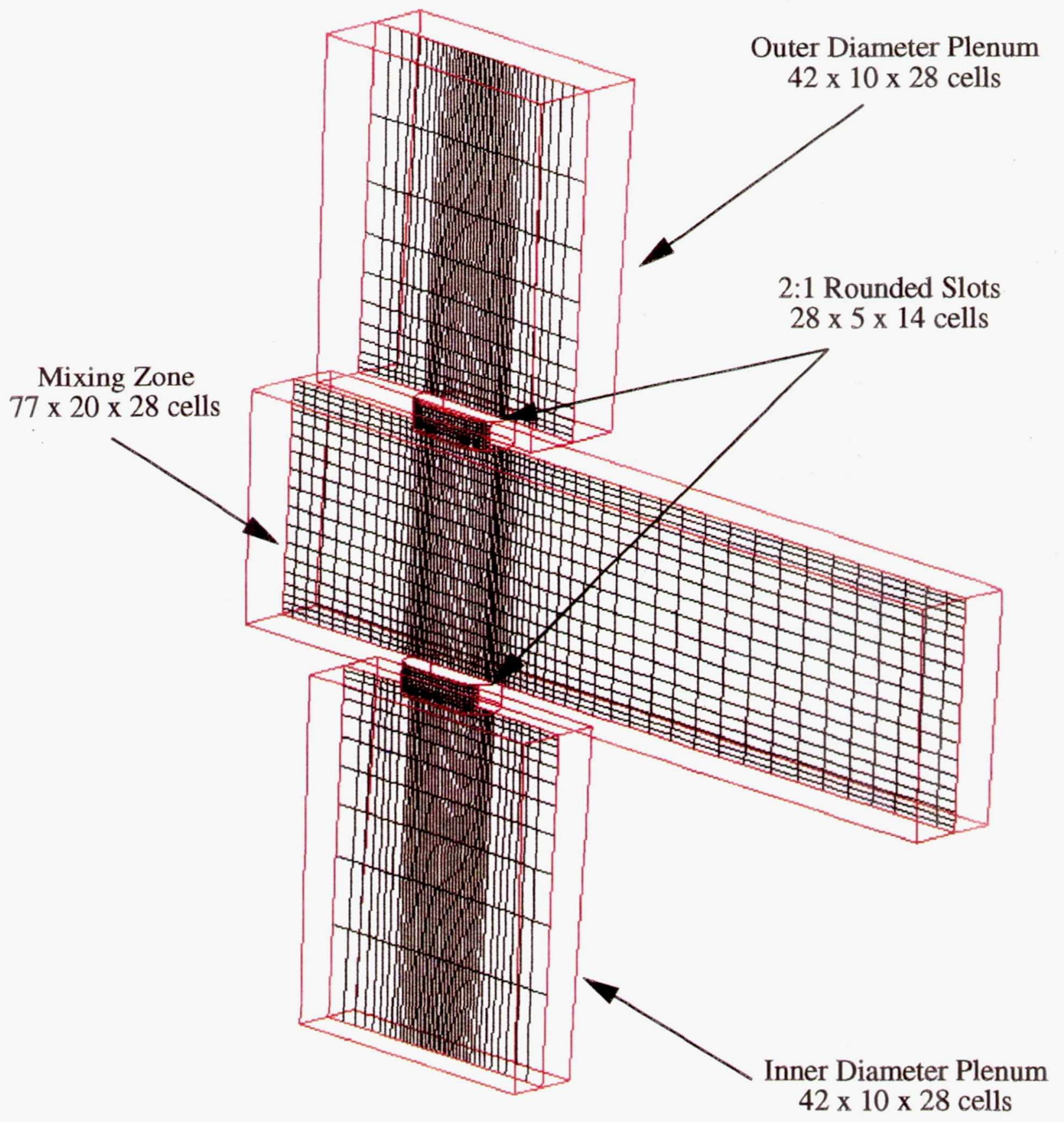

Figure 3. Typical Computational Mesh Used for Annular Parametric Analysis 
Page intentionally left blank 


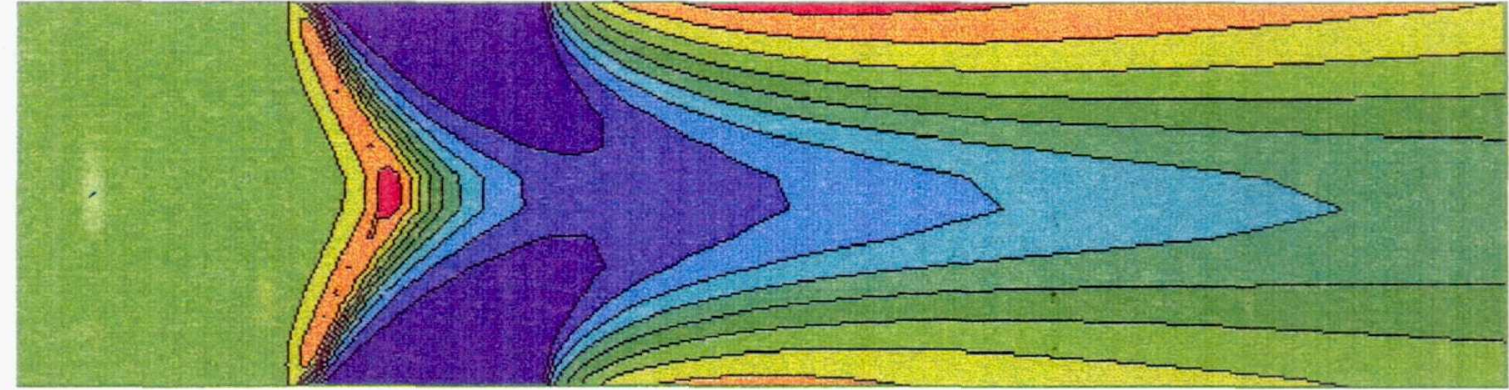

3ID/3OD (AN1)

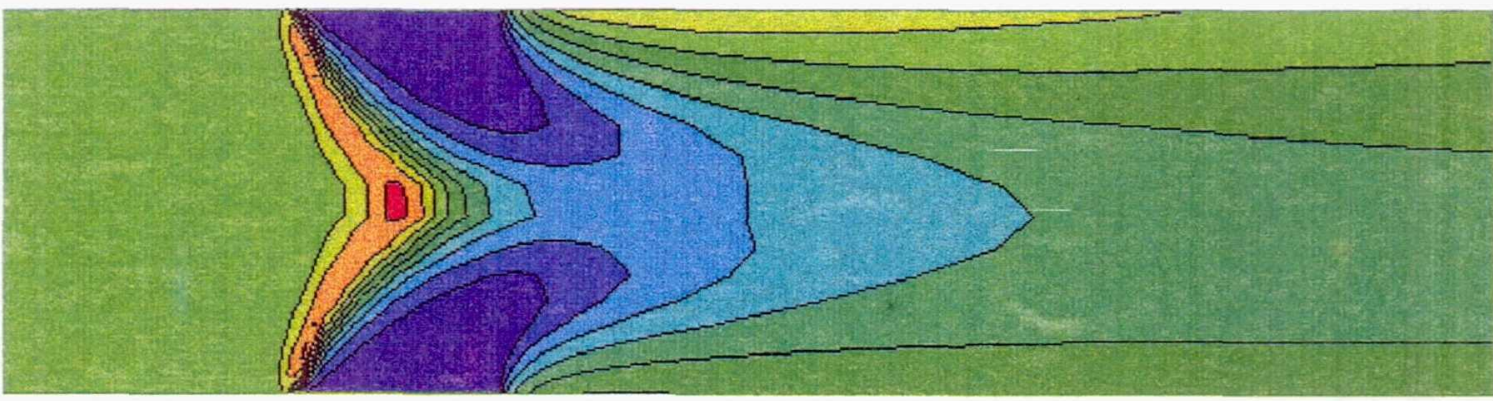

4ID/4OD (AN2)

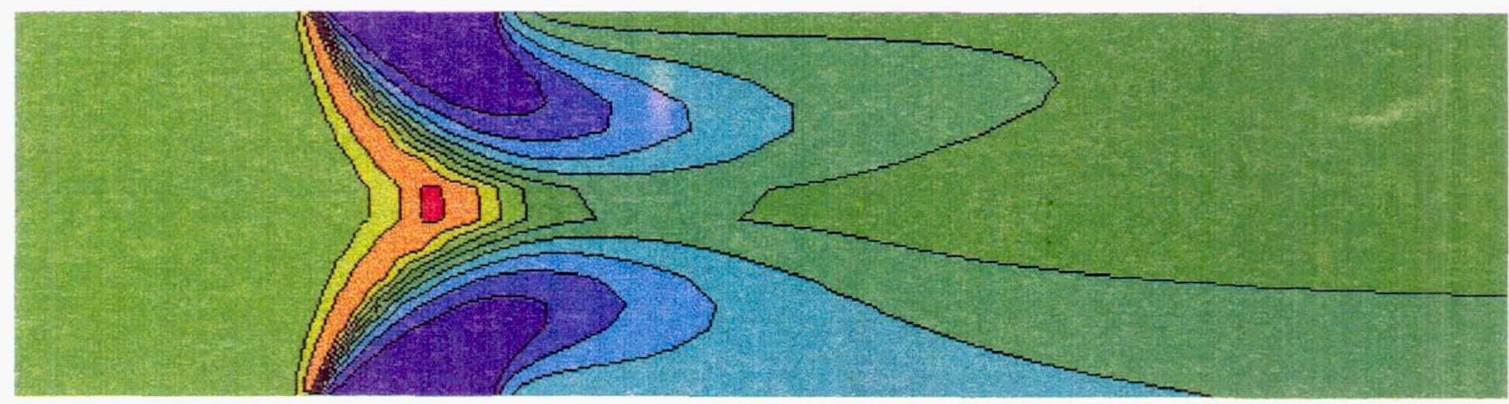

5ID/5OD (AN3)

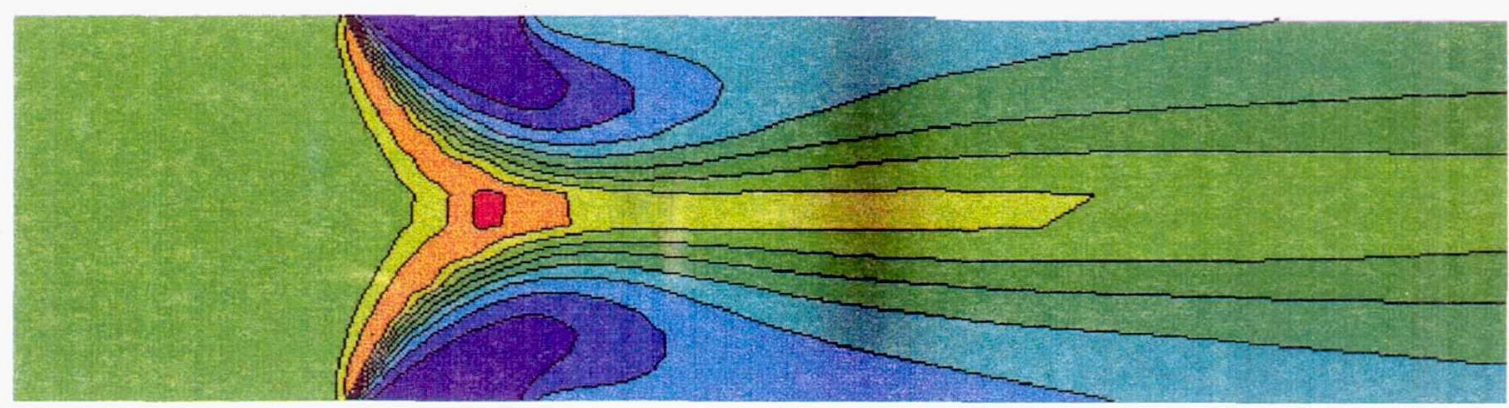

6ID/6OD (AN4)
Temperature $(\mathrm{K})$
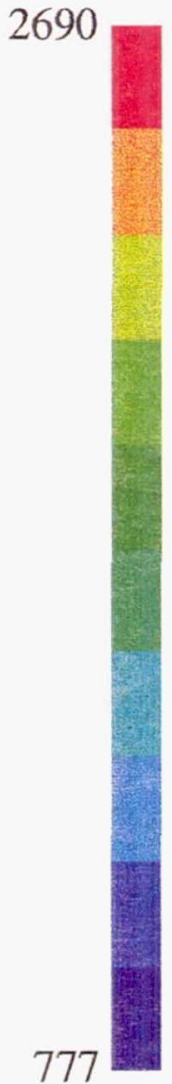

777

Figure 4. Temperature Transverse Slices Taken at the Slot Centerline;Annular Geometry 
Page intentionally left blank 


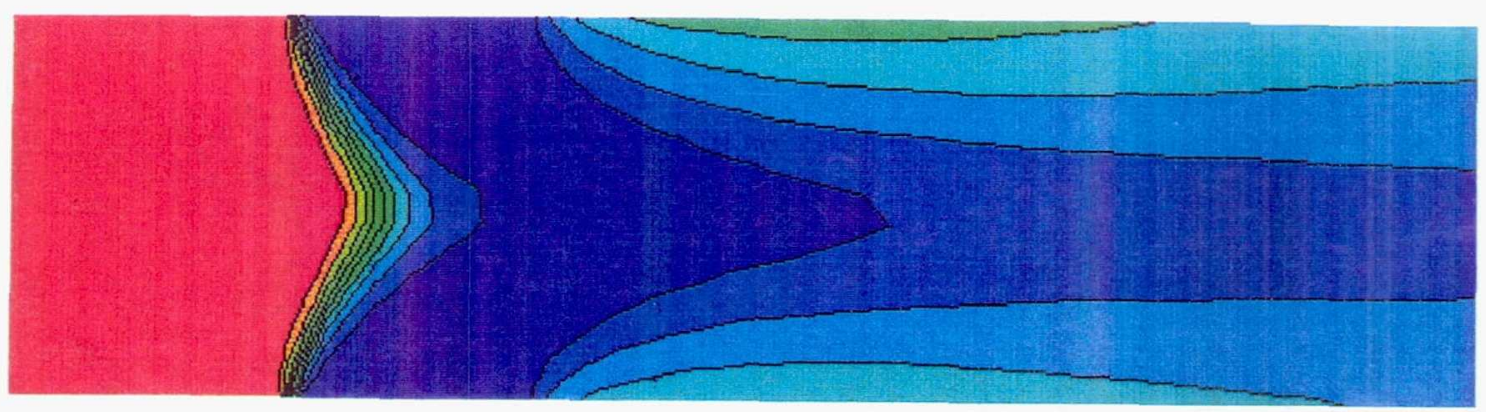

3ID/3OD (AN1)

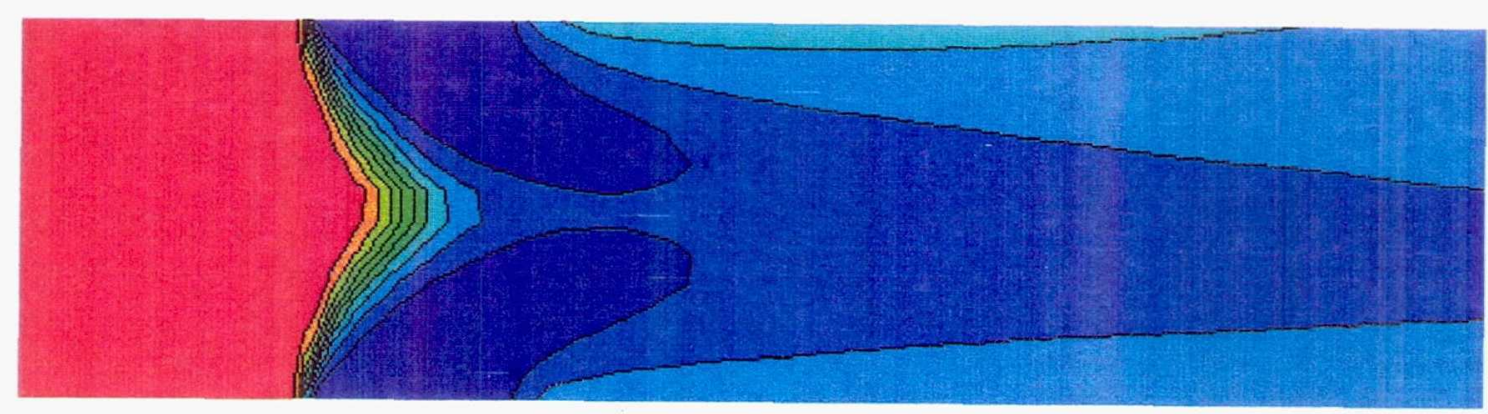

Equivalence Ratio

4ID/4OD (AN2)

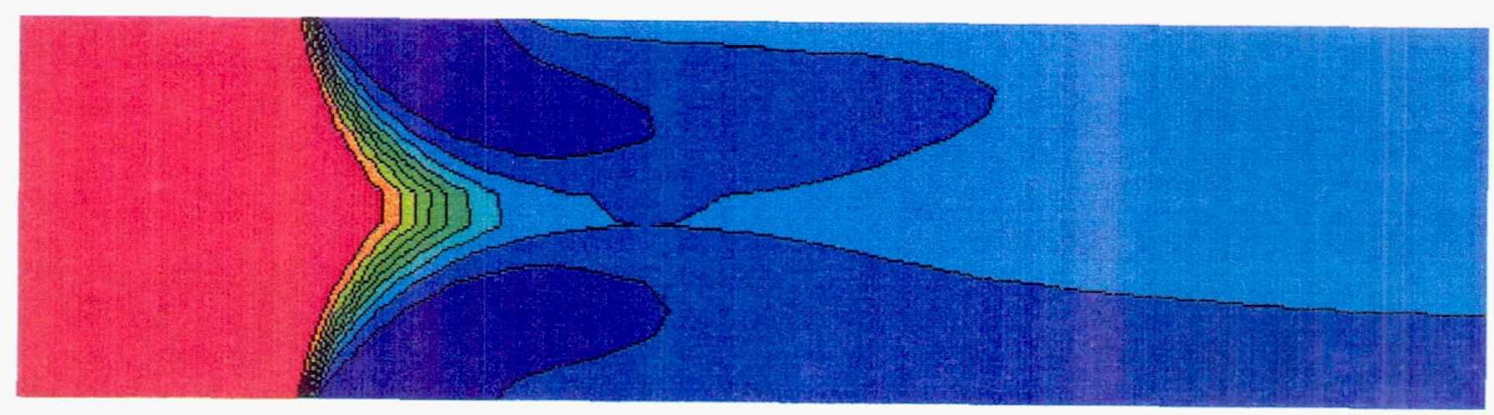

Equilibrium

5ID/5OD (AN3)
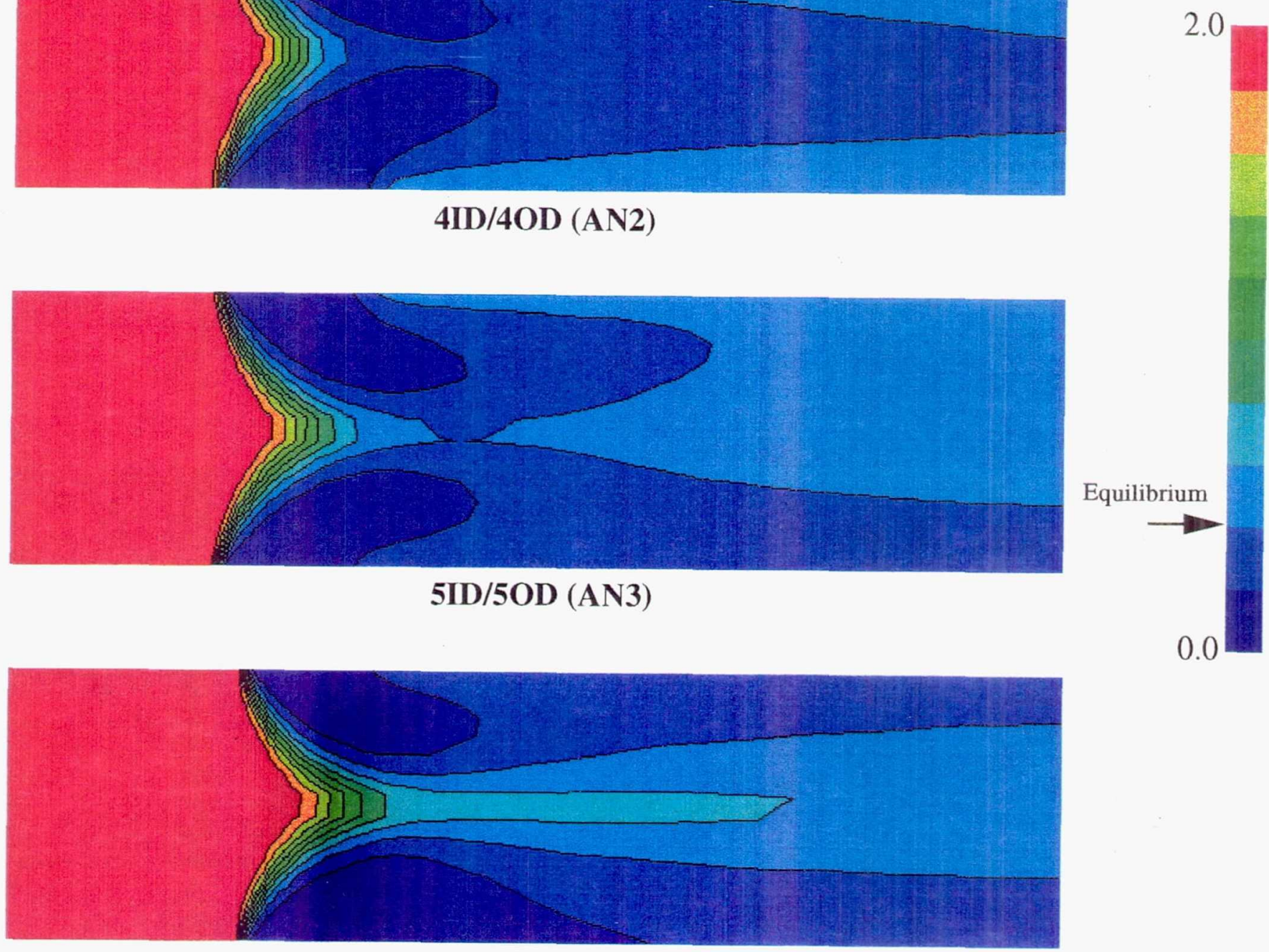

6ID/6OD (AN4)

Figure 5. Equivalence RatioTransverse Slices Taken at the Slot Centerline;Annular Geometry 
Page intentionally left blank 

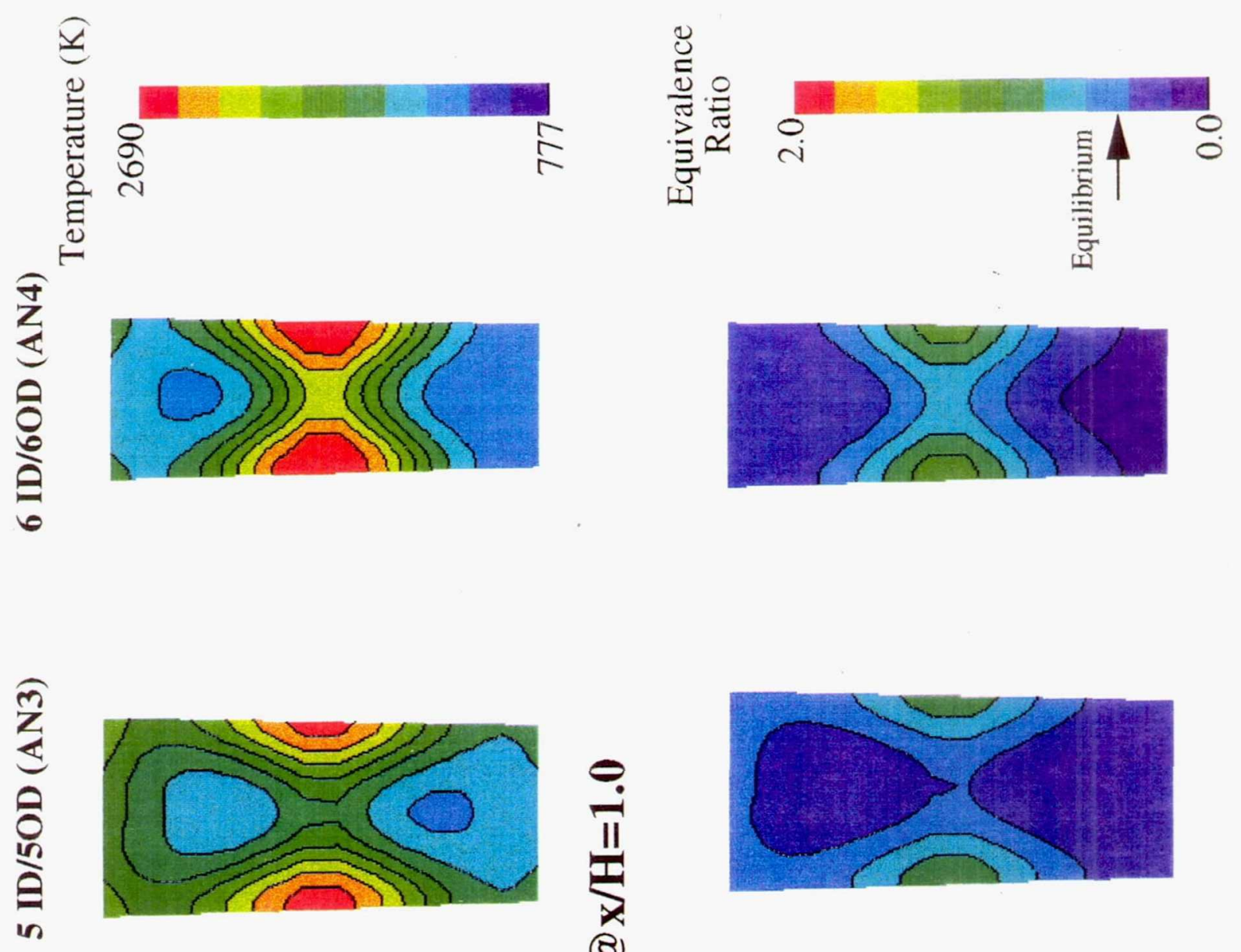

$\stackrel{ }{\text { II }}$
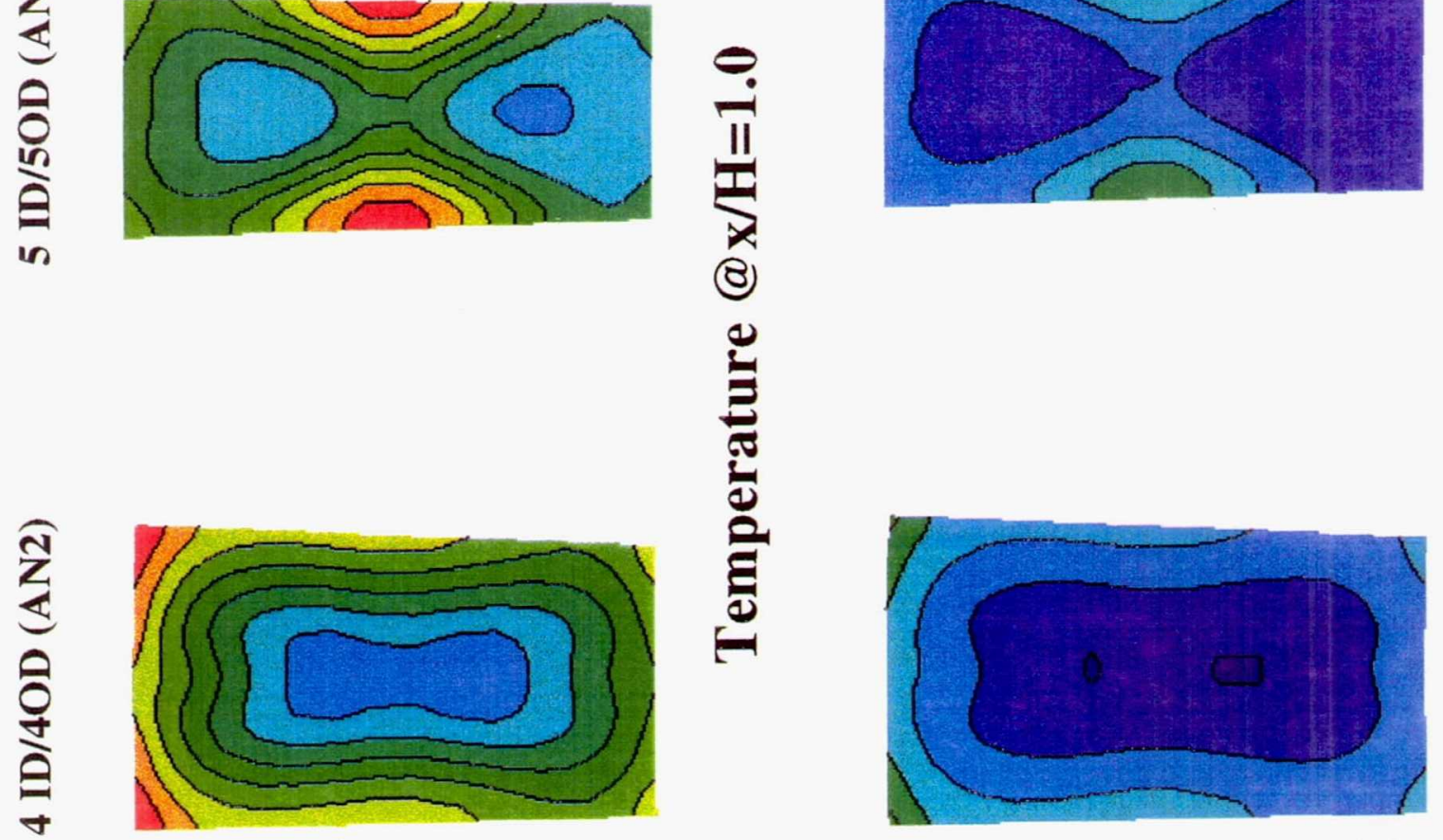

(e)
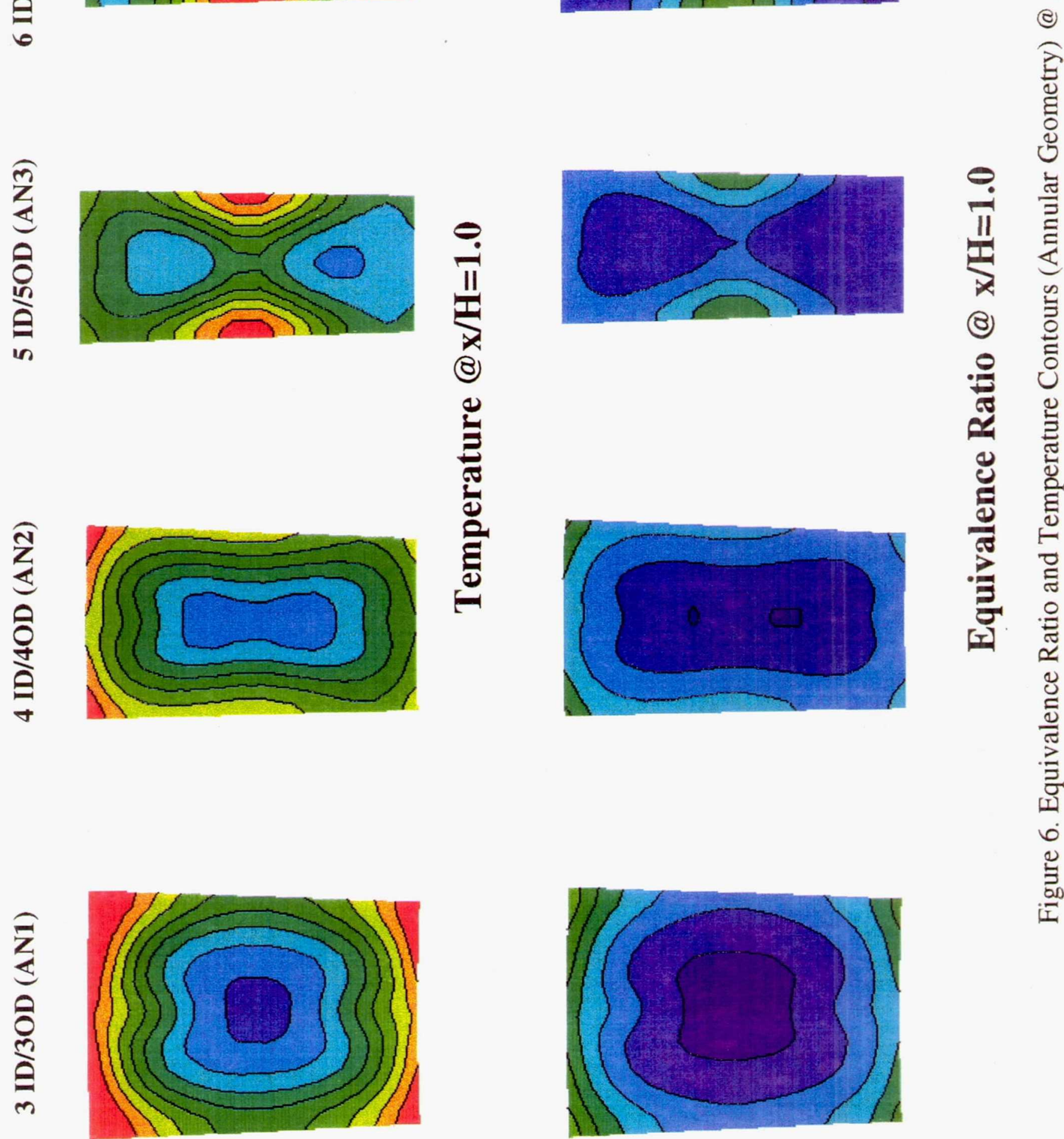

苟

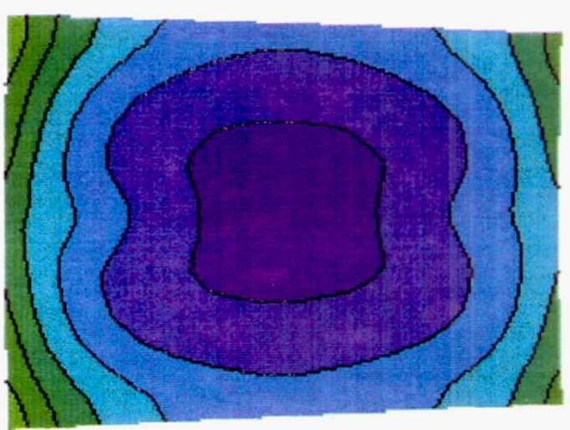

总 
Page intentionally left blank 


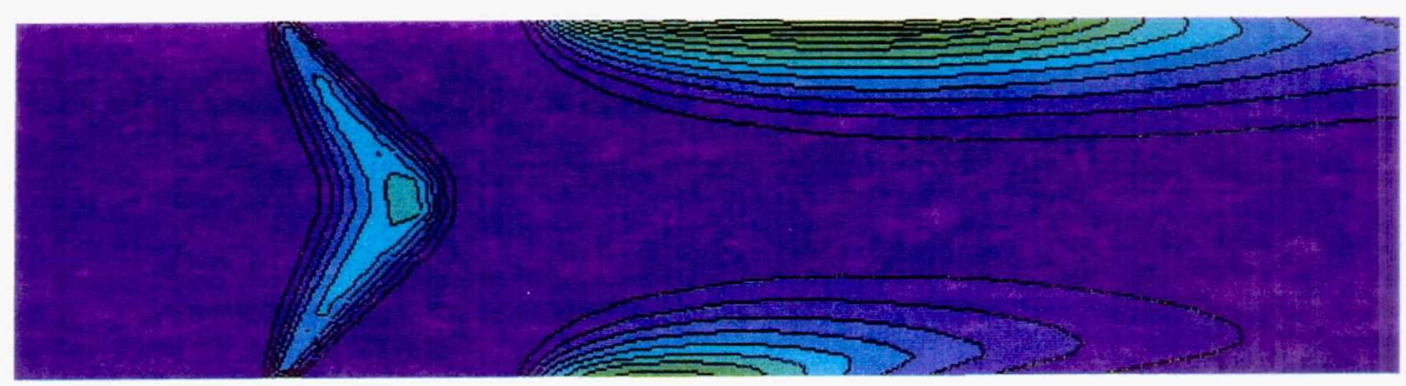

3ID/3OD (AN1)

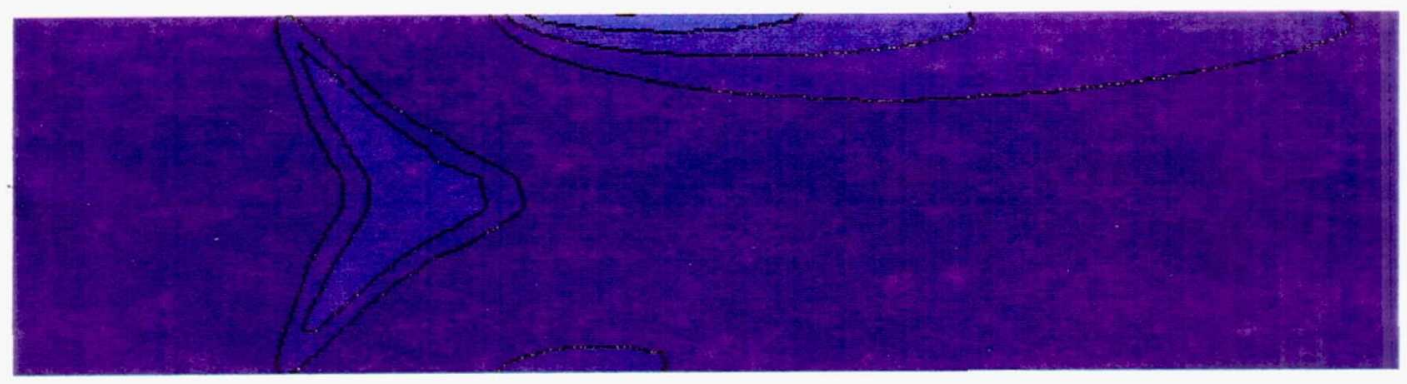

4ID/4OD (AN2)

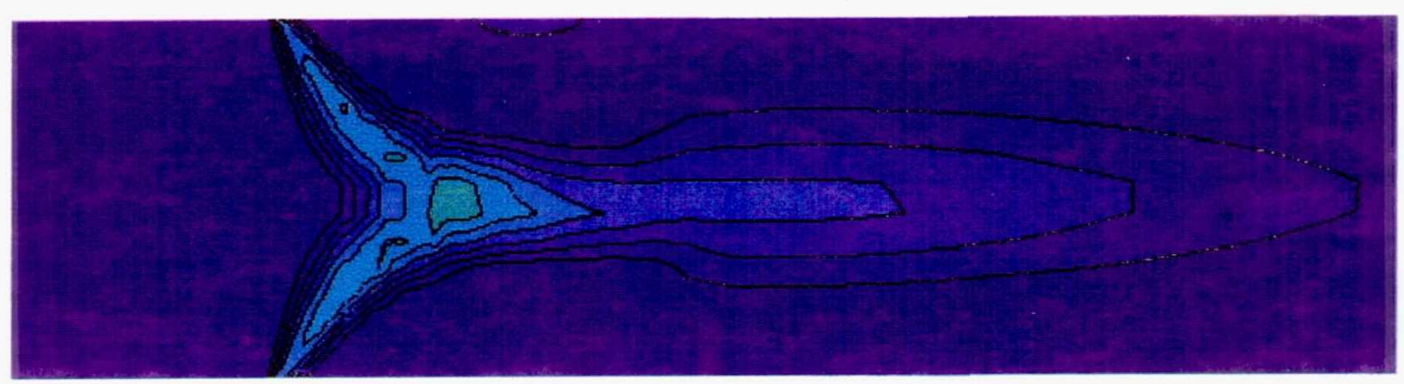

5ID/5OD (AN3)

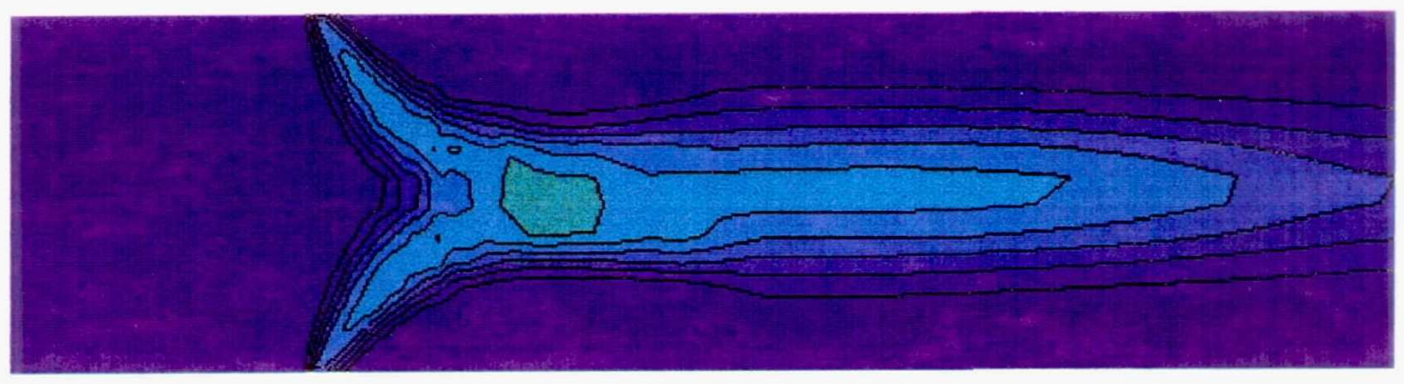

6ID/6OD (AN4)

Figure 7. $\mathrm{NO}_{\mathrm{X}}$ Production Contours for Annular Geometry 
Page intentionally left blank 


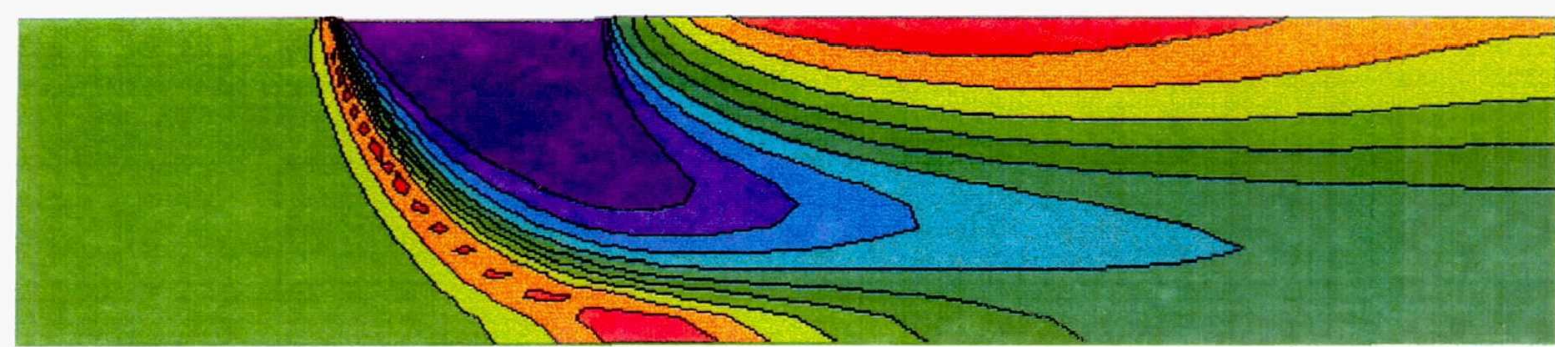

5 Orifices $(\mathrm{C} 1)$

Temperature $(\mathrm{K})$

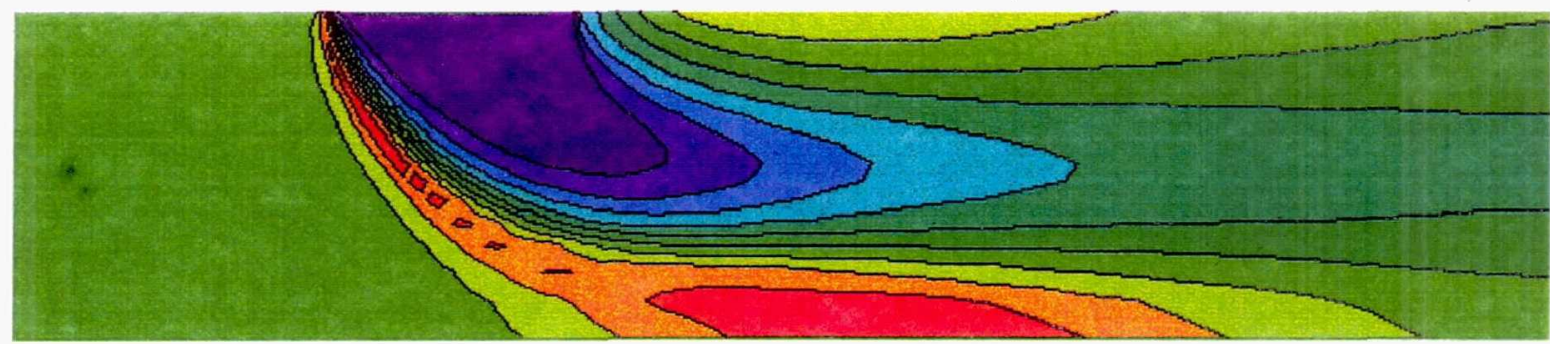

6 Orifices $(\mathrm{C} 2)$

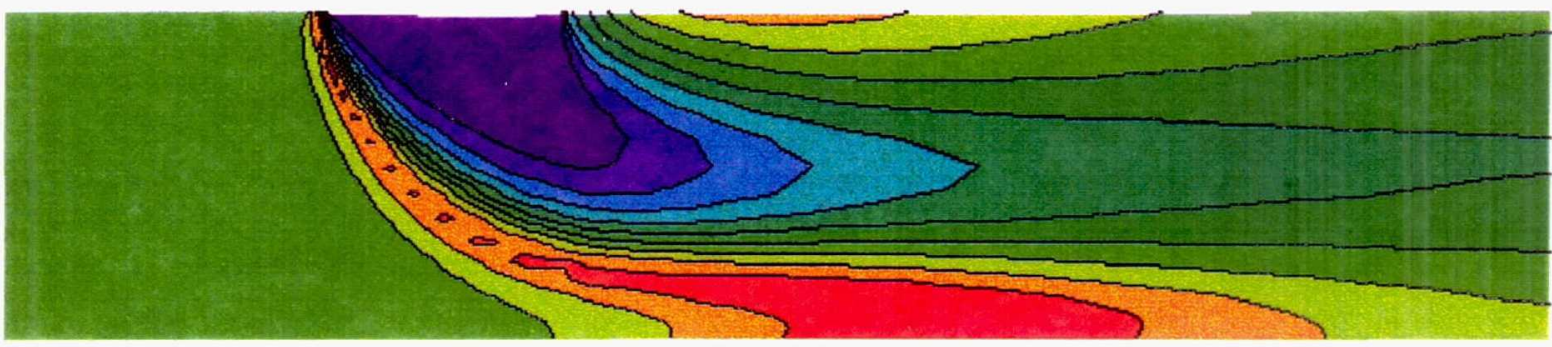

7 Orifices $(\mathrm{C} 3)$

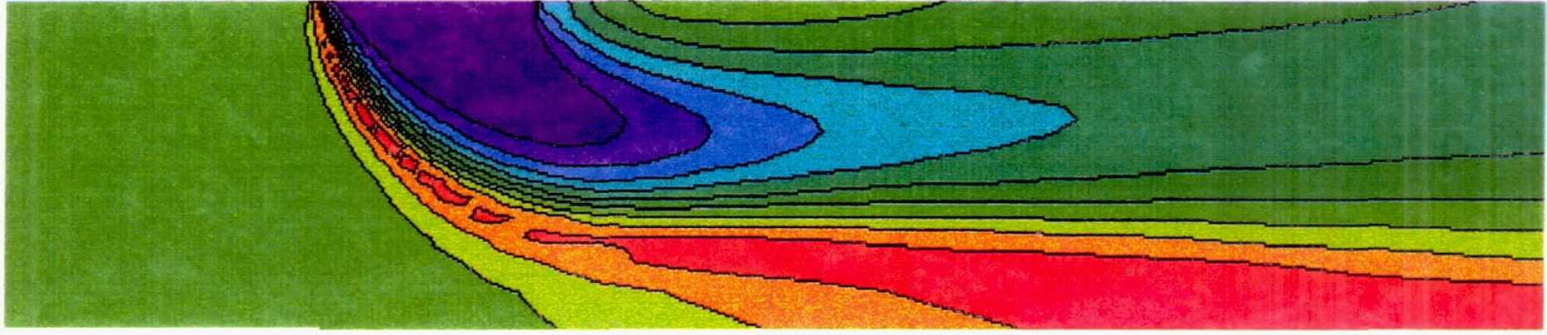

8 Orifices $(\mathrm{C} 4)$

Figure 8. Temperature Transverse Slices Taken at the Slot Centerline; Can Geometry 
Page intentionally left blank 


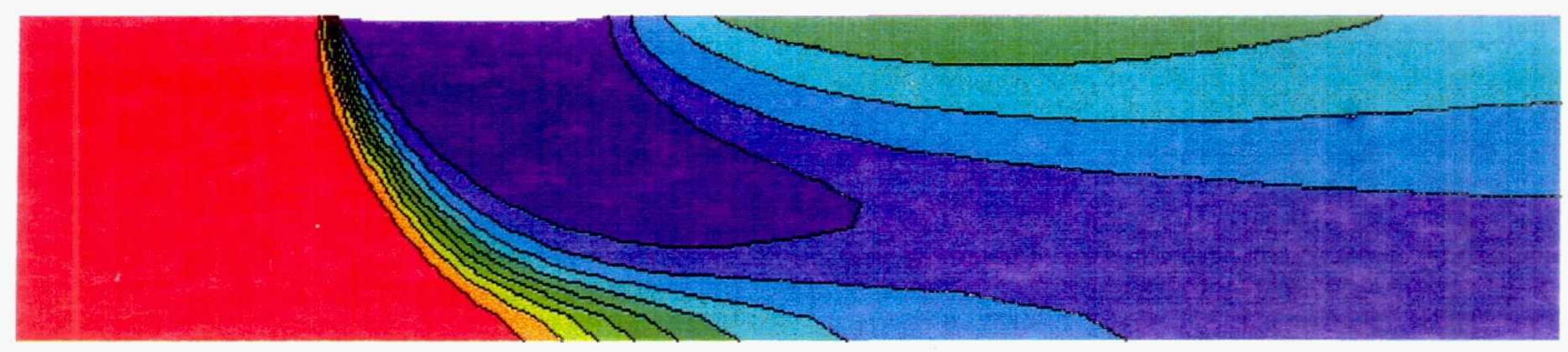

5 Orifices (C1)

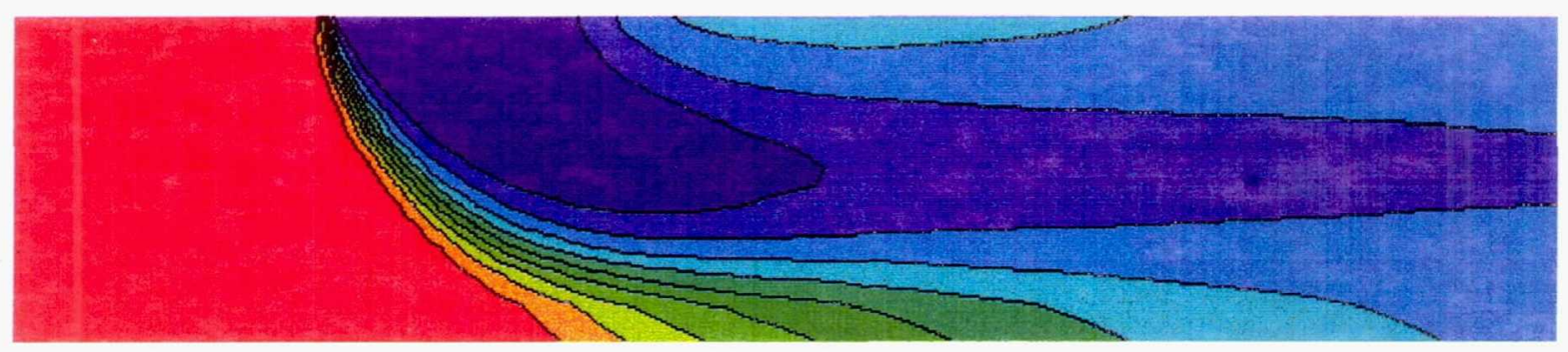

Equivalence

Ratio

2.0

6 Orifices $(\mathrm{C} 2)$

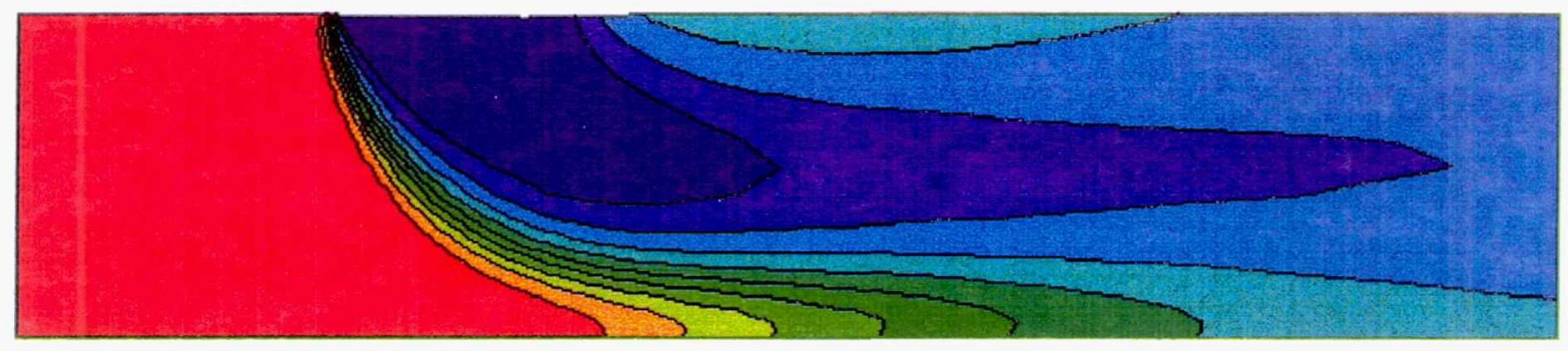

Equilibrium

\section{Orifices (C3)}

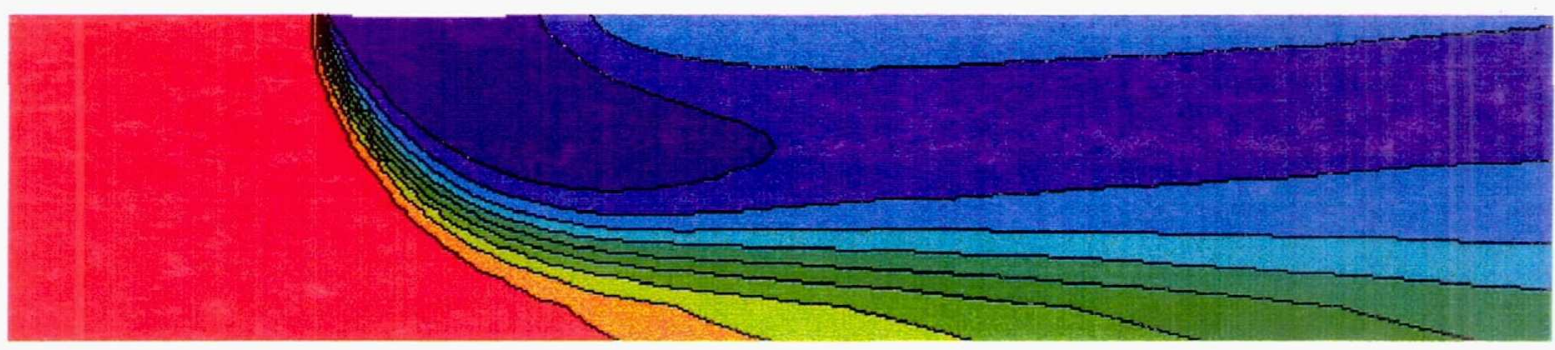

\section{Orifices $(\mathrm{C} 4)$}

Figure 9. Equivalence Ratio Transverse Slices Taken at the Slot Centerline; Can Geometry 
Page intentionally left blank 

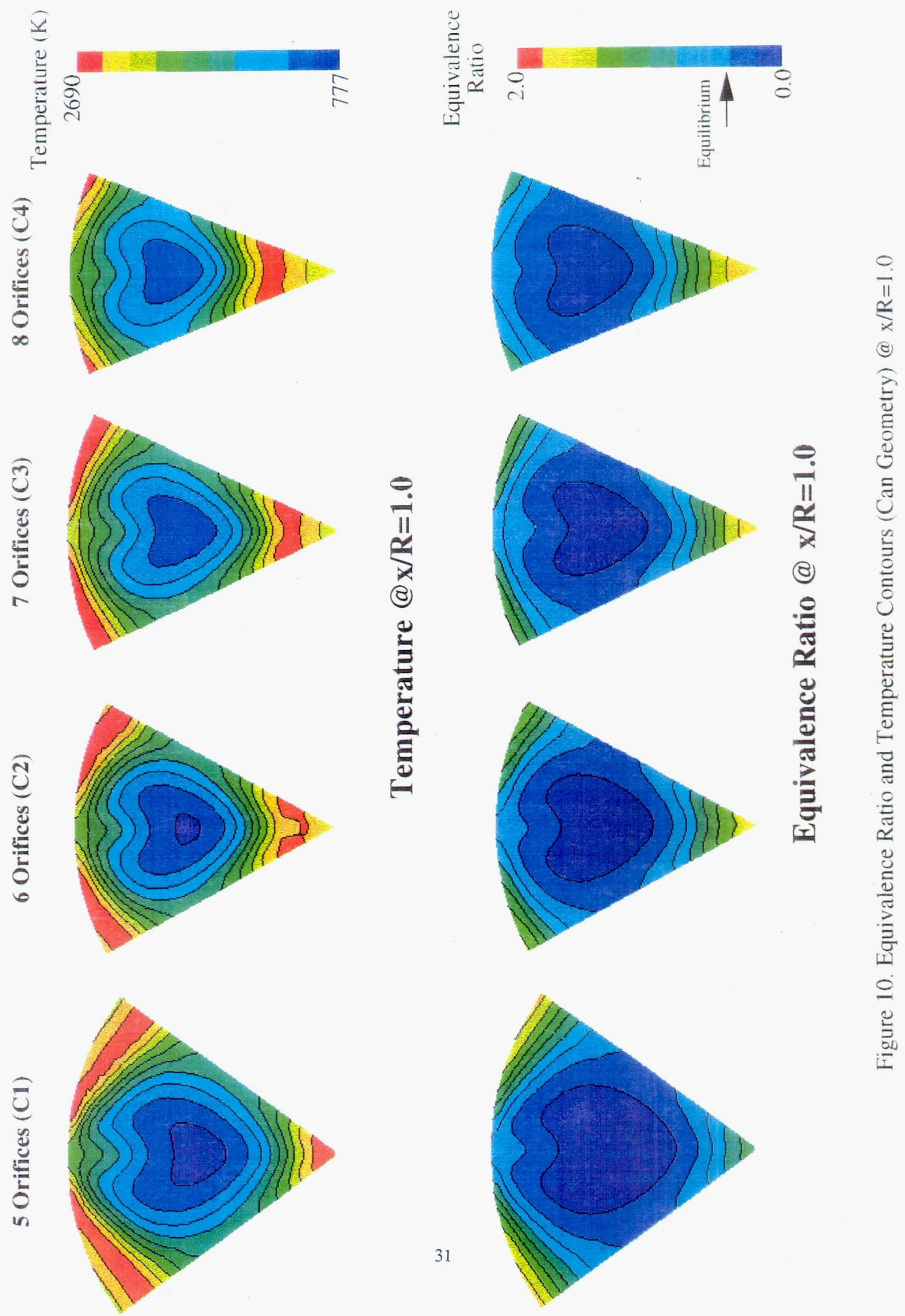
Page intentionally left blank 


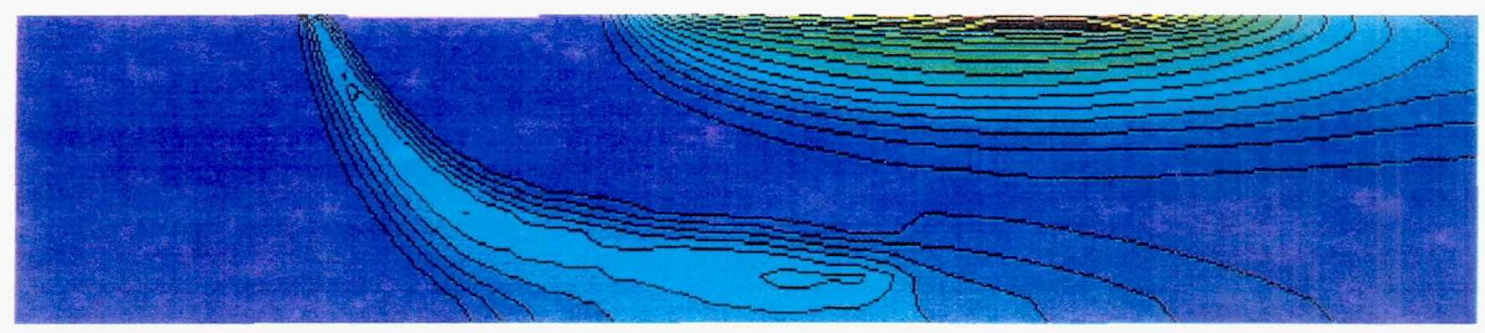

5 Orifices $(\mathrm{C} 1)$

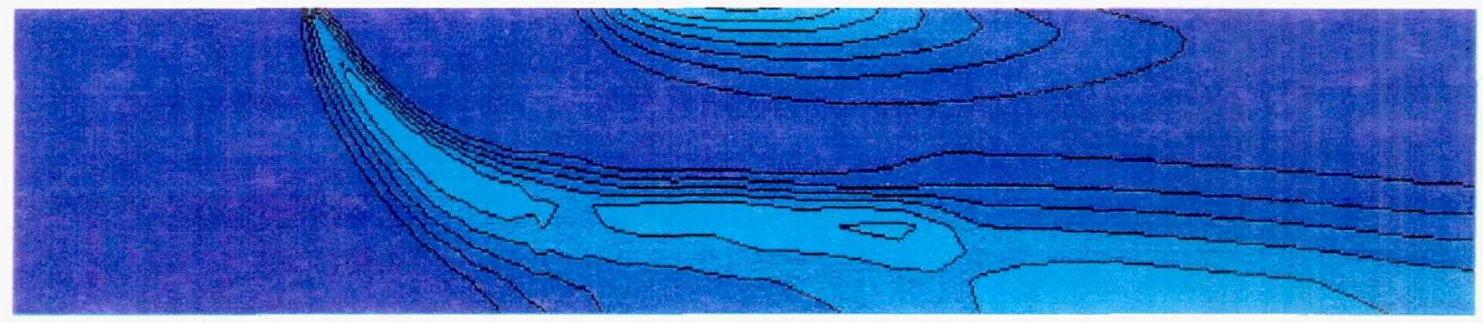

$\mathrm{NO}_{X}$

Production

$\left(\mathrm{kg} / \mathrm{m}^{3}-\mathrm{sec}\right)$

2.0

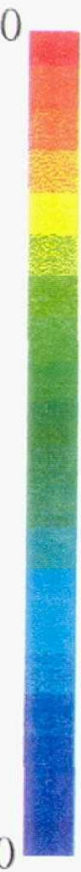

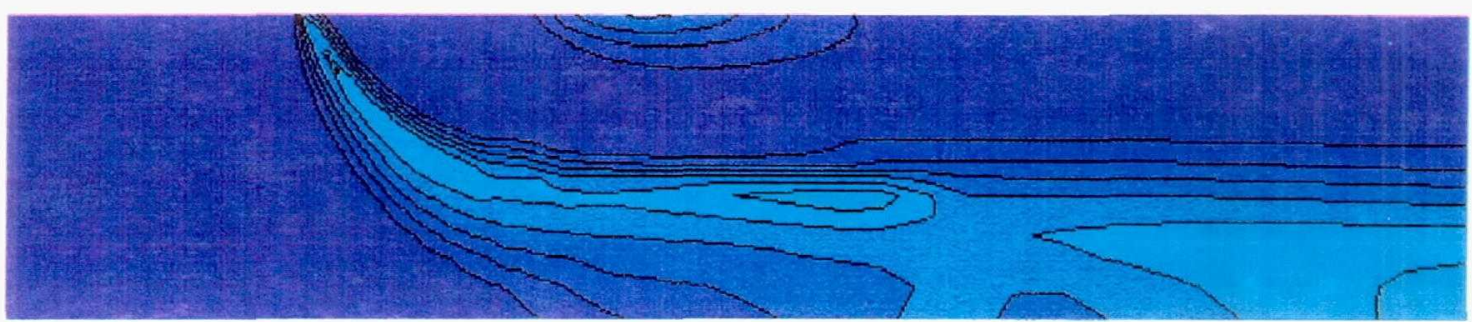

8 Orifices (C4)

Figure 11. $\mathrm{NO}_{\mathrm{X}}$ Production Terms Contours for Can Geometry 
Page intentionally left blank 


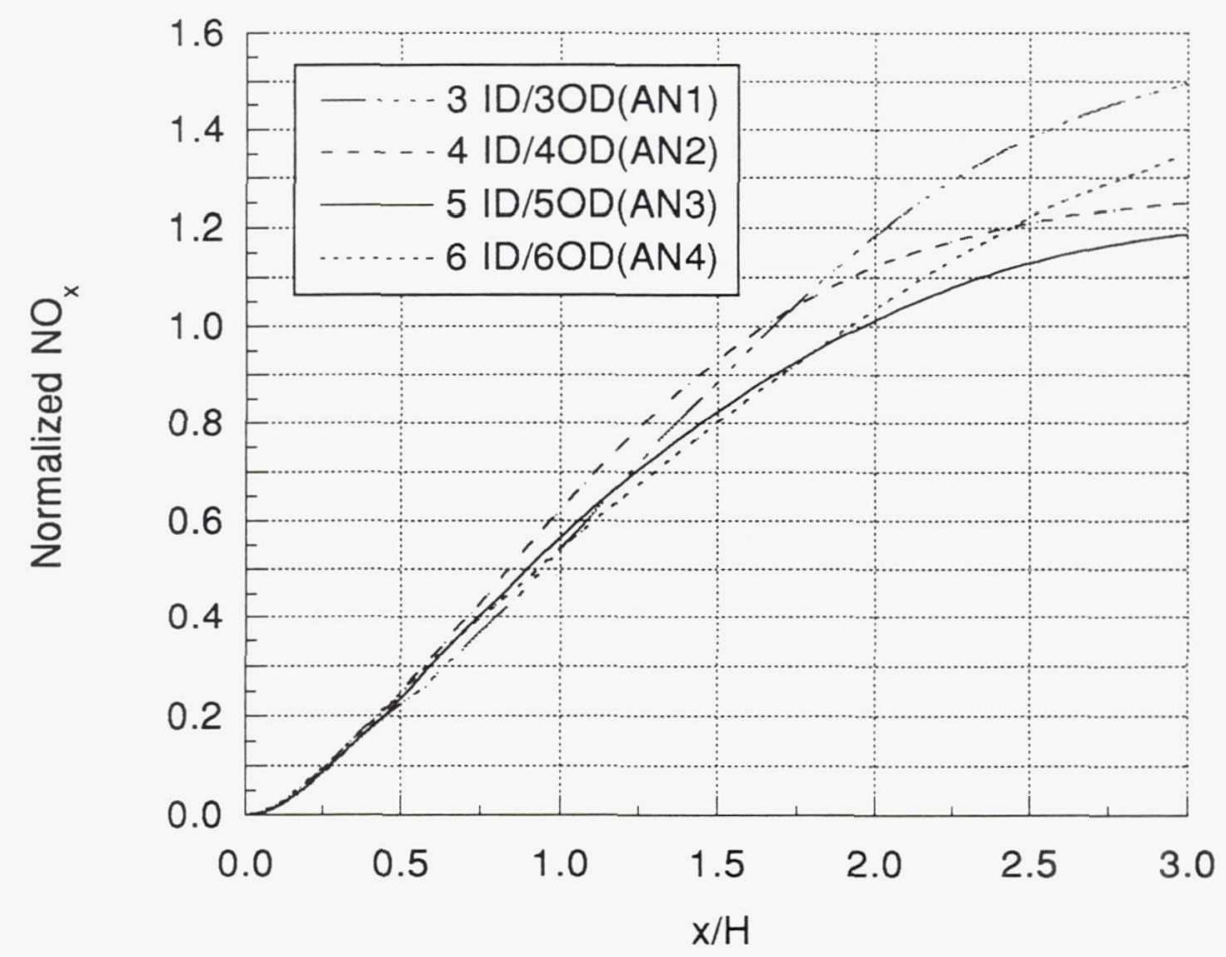

Figure 12. Normalized $\mathrm{NO}_{x}$ Curves for Annular Geometry 
Page intentionally left blank 

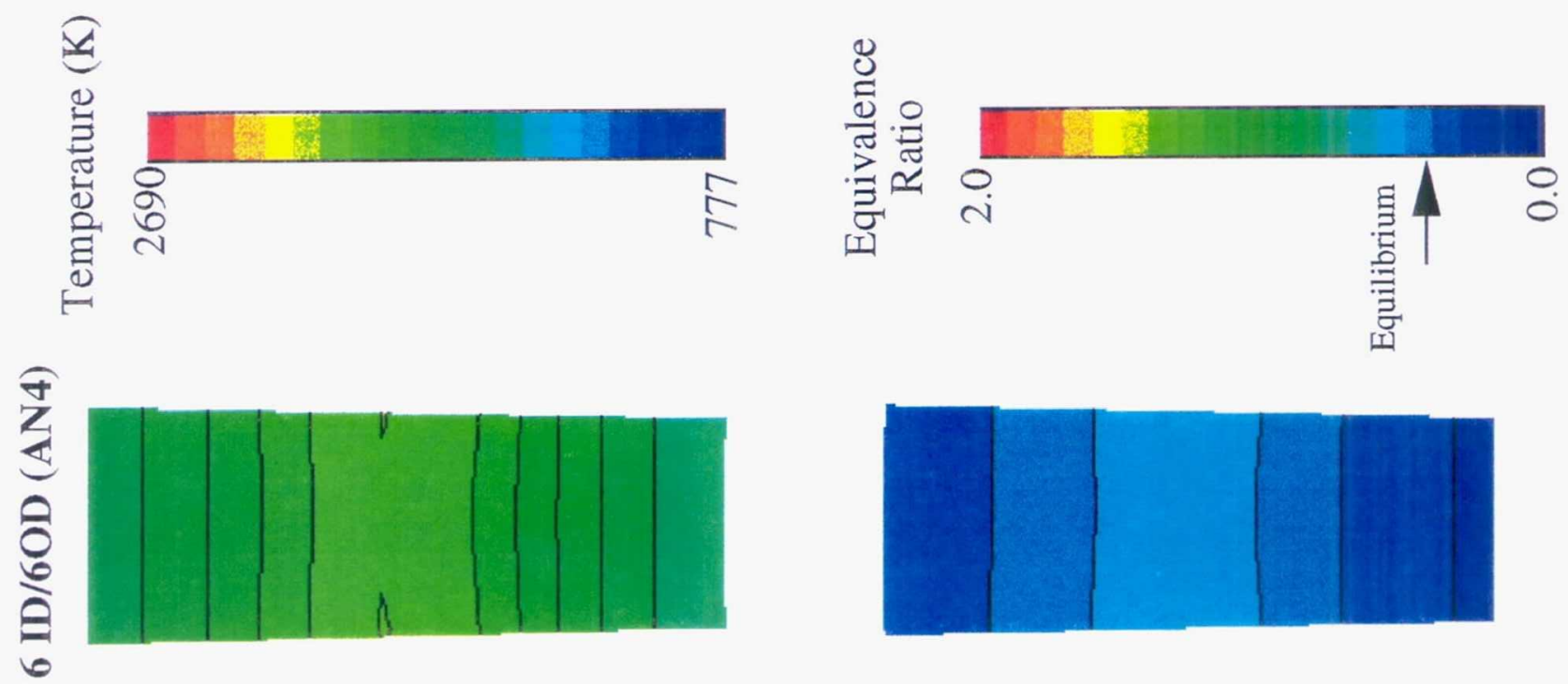

II
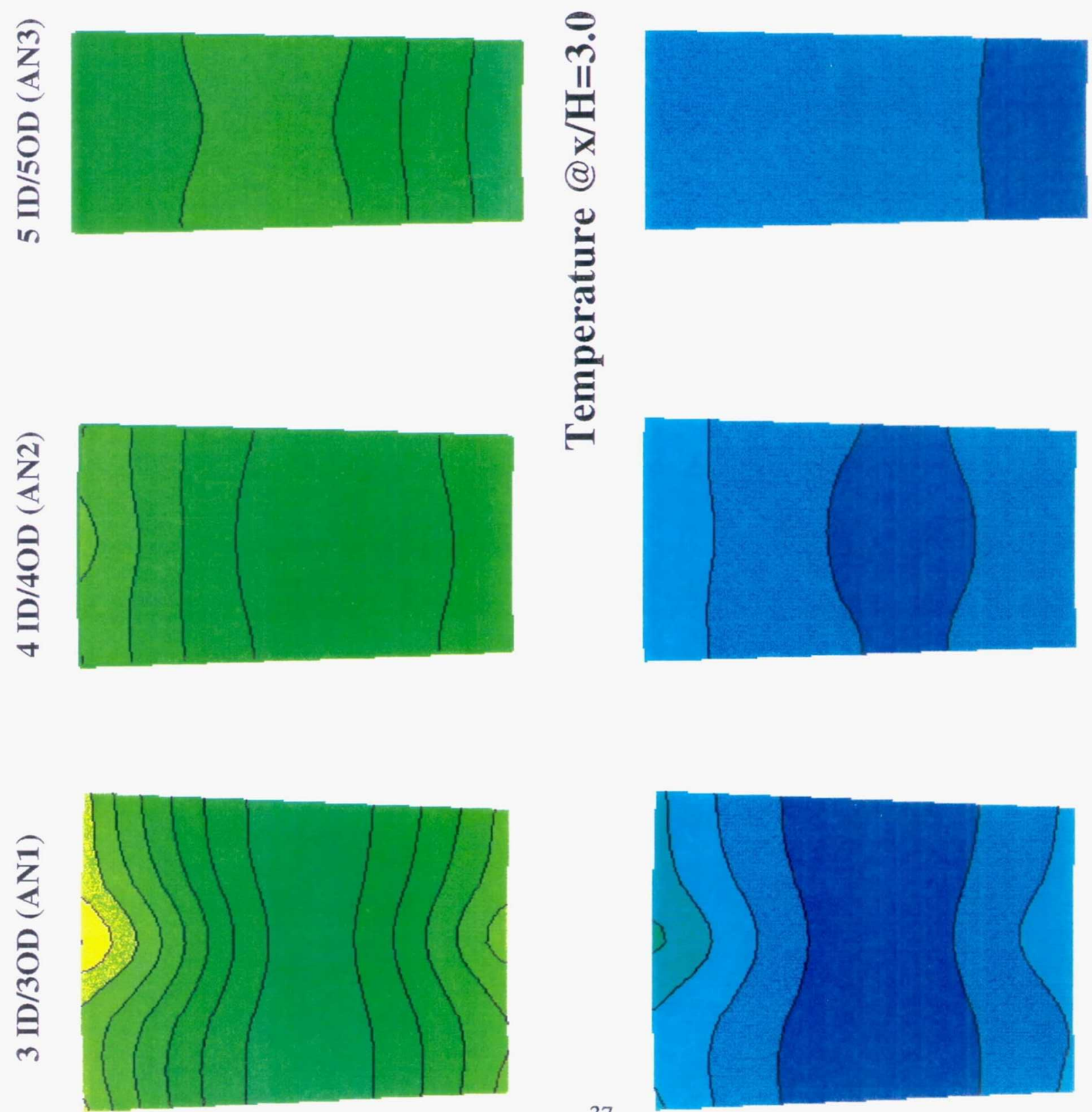
Page intentionally left blank 


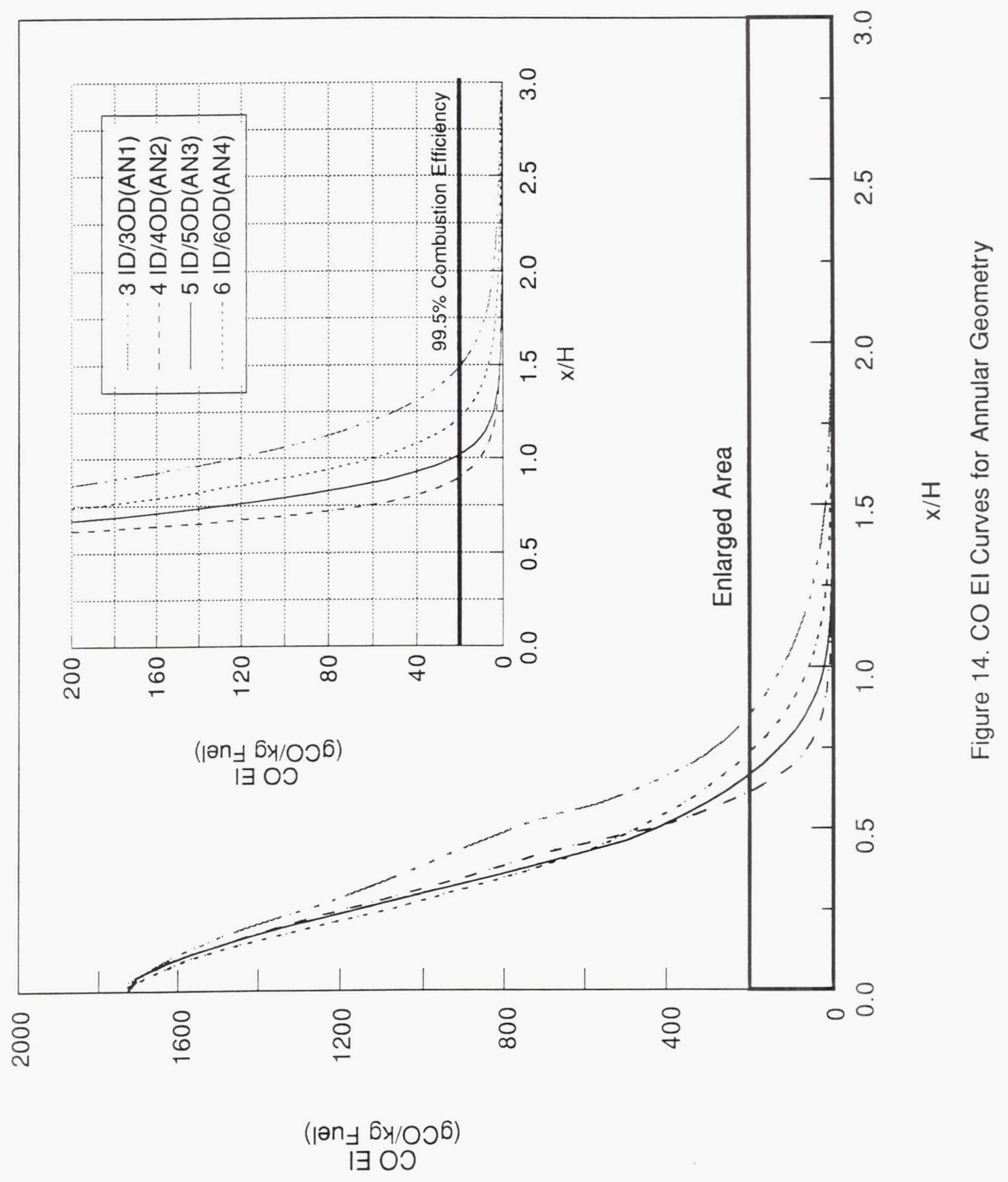




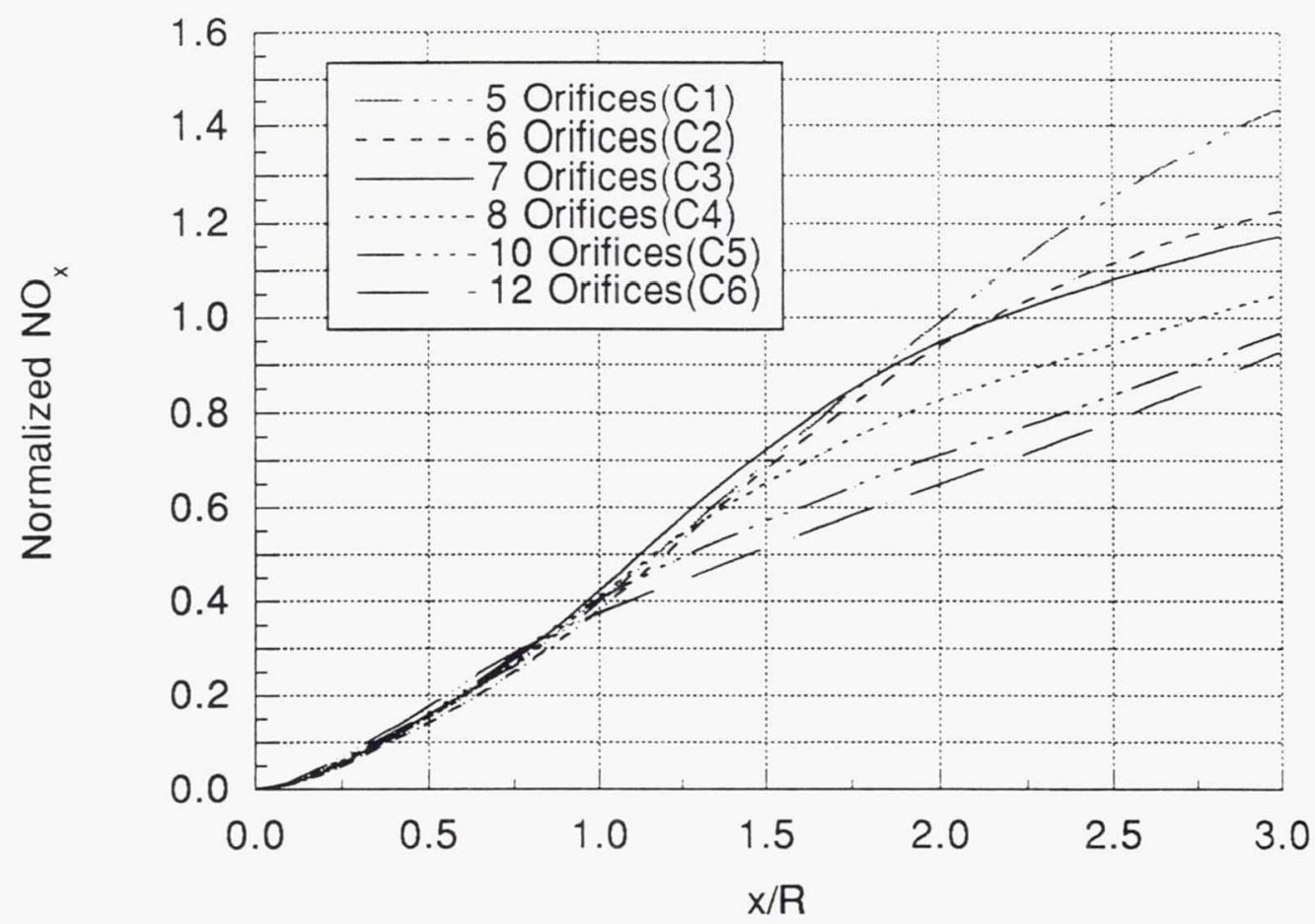

Figure 15. Normalized $\mathrm{NO}_{x}$ Curves for Can Geometry 


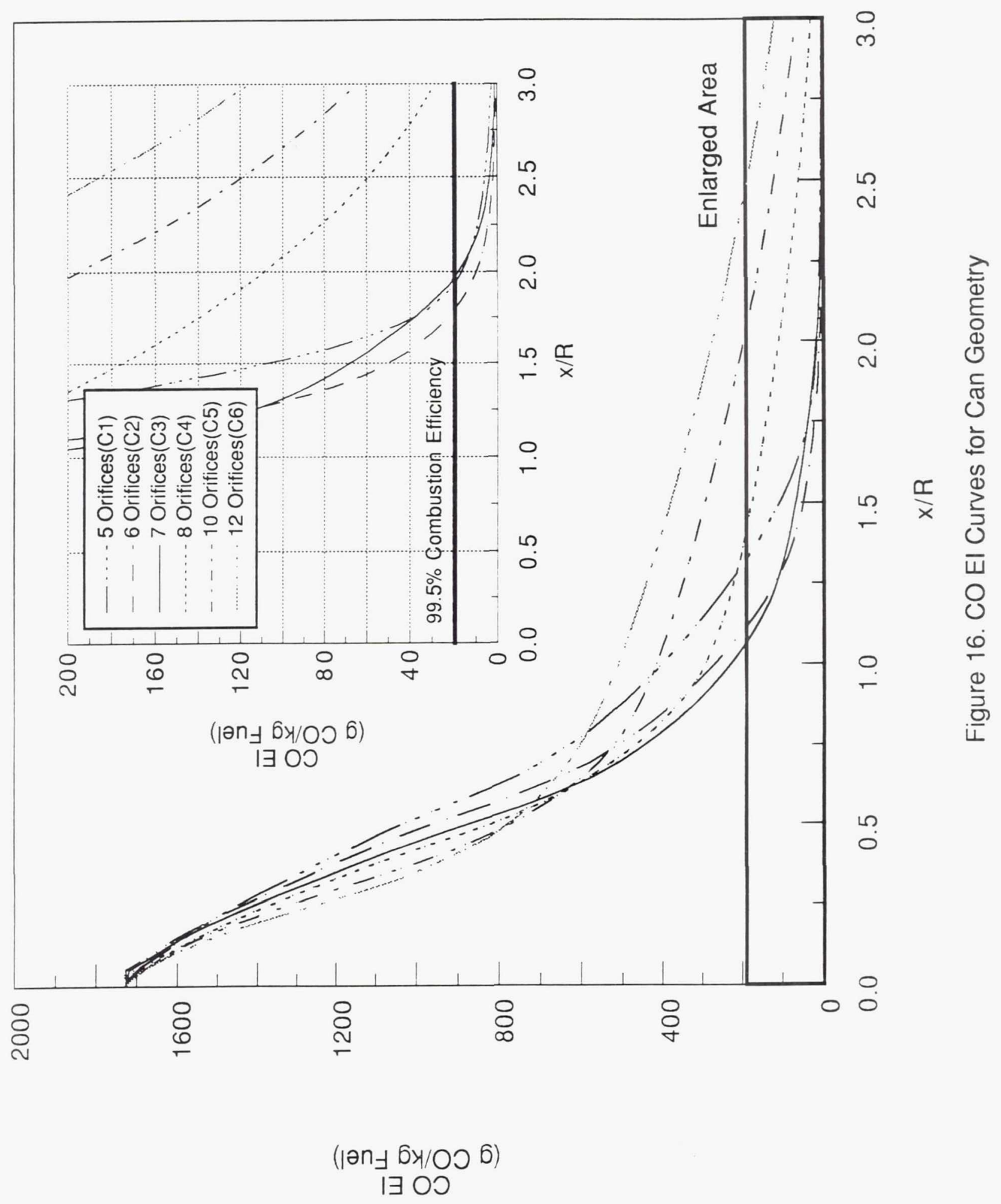




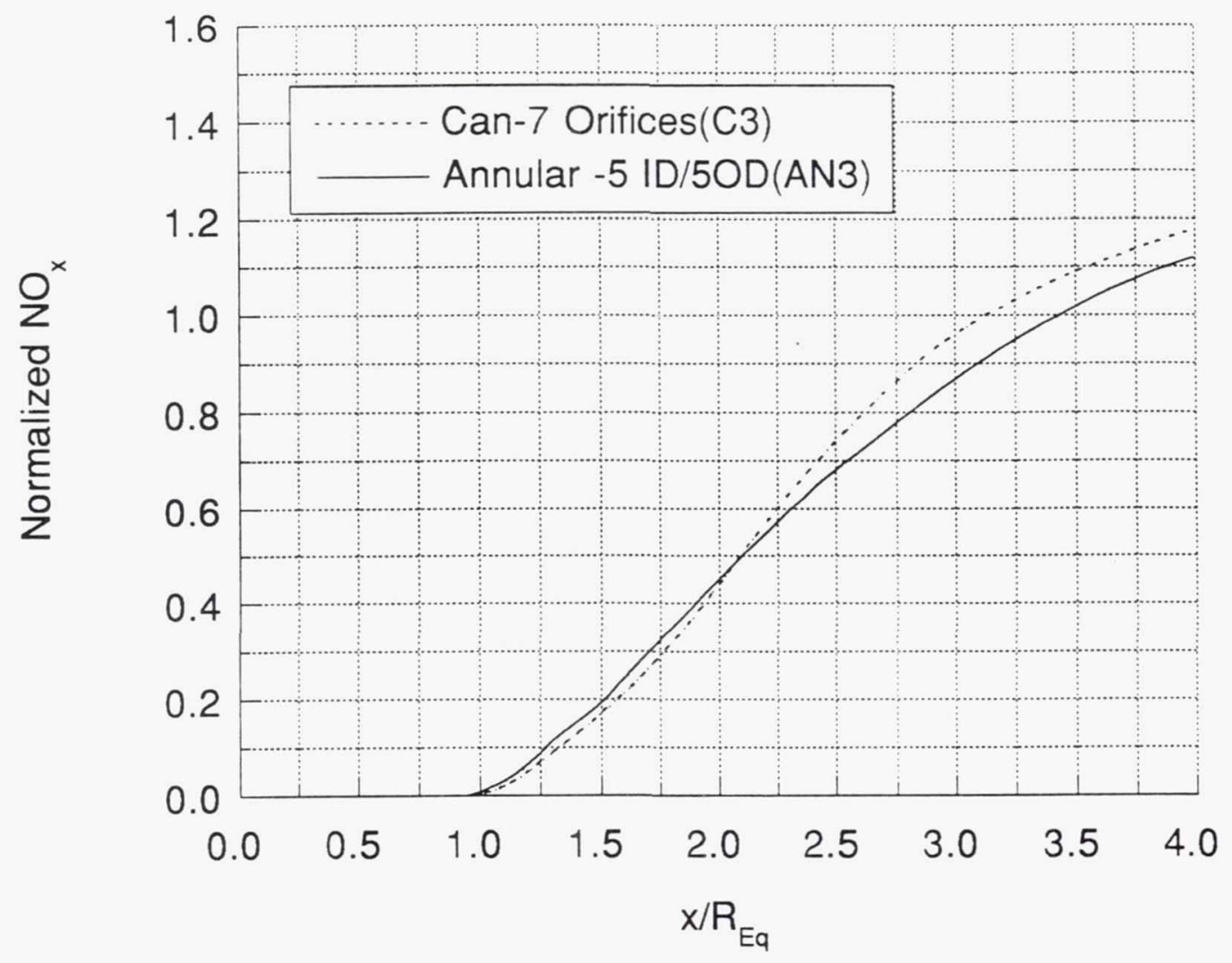

Figure 17. Comparison of Optimum Can and Annular Normalized $\mathrm{NO}_{x}$ 
Public reporting burden for this collection of information is estimated to average 1 hour per response, including the time for reviewing instructions, searching existing data sources, gathering and maintaining the data needed, and completing and reviewing the collection of information. Send comments regarding this burden estimate or any other aspect of this Davis Highway, Suite 1204, Arlington, VA 22202-4302, and to the Office of Management and Budget, Paperwork Reduction Project (0704-0188), Washington, DC 20503.

\begin{tabular}{|l|l|l|}
\hline 1. AGENCY USE ONLY (Leave blank) & $\begin{array}{c}\text { 2. REPORT DATE } \\
\text { July } 1995\end{array}$ & $\begin{array}{r}\text { 3. REPORT TYPE AND DATES COVERED } \\
\text { Technical Memorandum }\end{array}$ \\
\hline
\end{tabular}

\section{TITLE AND SUBTITLE}

Jet Mixing and Emission Characteristics of Transverse Jets in Annular and Cylindrical Confined Crossflow

\section{AUTHOR(S)}

D.B. Bain, C.E. Smith, and J.D. Holdeman
5. FUNDING NUMBERS

WU-537-02-21

\section{PERFORMING ORGANIZATION NAME(S) AND ADDRESS(ES)}

National Aeronautics and Space Administration

Lewis Research Center

Cleveland, Ohio 44135-3191
8. PERFORMING ORGANIZATION REPORT NUMBER

E-9737
9. SPONSORING/MONITORING AGENCY NAME(S) AND ADDRESS(ES)

National Aeronautics and Space Administration

Washington, D.C. 20546-0001
10. SPONSORING/MONITORING AGENCY REPORT NUMBER

NASA TM-106976

AIAA-95-2995

\section{SUPPLEMENTARY NOTES}

Prepared for the 31st Joint Propulsion Conference and Exhibit cosponsored by AIAA, ASME, SAE, and ASEE, San Diego, California, July 10-12, 1995. D.B. Bain and C.E. Smith, CFD Research Corporation, Huntsville, Alabama; J.D. Holdeman, NASA Lewis Research Center. Responsible person, J.D. Holdeman, organization code 2650, (216) 433-5846.

12a. DISTRIBUTKONAVAILABILTYY STATEMENT

12b. DISTRIBUTION CODE

Unclassified -Unlimited

Subject Category 07

This publication is available from the NASA Center for Aerospace Information, (301) 621-0390.

13. ABSTRACT (Maximum 200 words)

3-D turbulent reacting CFD analyses were performed on transverse jets injected into annular and cylindrical (can) confined crossflows. The goal of this study was to identify and assess mixing differences between annular and can geometries. The approach was to optimize both annular and can configurations by systematically varying orifice spacing until lowest emissions were achieved, and then compare the results. Numerical test conditions consisted of a jet-tomainstream mass-flow ratio of 3.2 and a jet-to-mainstream momentum-flux ratio (J) of 30 . The computational results showed that the optimized geometries had similar emission levels at the exit of the mixing section although the annular configuration did mix-out faster. For lowest cmissions, the design correlation parameter $(C=(S / H) \sqrt{ })$ was 2.35 for the annular geometry and 3.5 for the can geometry. For the annular geometry, the constant was about twice the value seen for jet mixing at low mass-flow ratios (i.e. MR $<0.5$ ). For the can geometry, the constant was about $11 / 2$ times the value seen for low mass-flow ratios.

14. SUBJECT TERMS

Dilution; Jet mixing; Gas turbine; Combustion chamber; Emissions

15. NUMBER OF PAGES 32

16. PRICE CODE

$\mathrm{A03}$

17. SECURTY CLASSIFICATION OF REPORT

Unclassified

18. SECURTYY CLASSIFICATION OF THIS PAGE

Unclassified

9. SECURITY CLASSIFICATION OF ABSTRACT

Unclassified 